\title{
FLORA MALESIANA PRECURSOR FOR THE TREATMENT OF MORACEAE 5: FICUS SUBGENUS SYCIDIUM
}

\author{
C.C. BERG \\ The Norwegian Arboretum/Botanical Institute, University of Bergen, \\ N-5259 Hjellestad, Norway; Nationaal Herbarium Nederland, Universiteit Leiden branch, \\ P.O. Box 9514, 2300 RA Leiden, The Netherlands
}

\section{SUMMARY}

The sections of Ficus subg. Sycidium are described and their Malesian species listed and keyed out. Six new species are described in the subgenus: F. floresana, F. funiculicaulis, F. kuchinensis, F. myiopotamica, F. sandanakana, and F. stellaris. The combination F. stellaris subsp. pallida (Corner) C.C. Berg is made.

Key words: Moraceae, Ficus subg. Sycidium, Malesia.

\section{INTRODUCTION}

Ficus subg. Sycidium is described and discussed in Flora Malesian Precursor 1 (Berg, 2003). The present contribution deals with the subdivision of this subgenus, lists the species currently recognised for the region and new species and subspecies discovered, and a key to the Malesian species. The formal subdivision is limited to sections in which a number of informal groups of presumably related species are distinguished; the ranks of series and subseries are not applied. Most of the varieties recognised by Corner $(1960 b, 1965)$ are not maintained, some are recognised as species, some others transferred to other species (as indicated in the list of species).

\section{SUBDIVISIONS AND SPECIES}

Ficus subg. Sycidium sect. Sycidium Miq. (1848) 228

Including: Ficus subg. Ficus sect. Sinosycidium Corner(1960c) 24 and Ficus subg. Ficus sect. Ficus subsect. Ficus ser. Sinosyceae Corner (1960a) 418.

Trees or shrubs, terrestrial, commonly with intermittent growth; aerial adventitious roots absent. Leafy twigs hollow or, if solid, then with ample pith, (sub)terete and mostly ribbed; hairs often with a swollen base and the longer brown ones often clustered. Leaves spirally alternate, (sub)opposite (or subverticillate) or distichously alternate, asymmetric to symmetric, often scabrous by rigid hairs or cystolith hairs; cystoliths mostly on both sides, less frequently only beneath; waxy glands in the axils of both lateral veins, sometimes largely on the midrib and then separate or fused, or sometimes absent, rarely 1 in the axils of one of the basal pair, smaller glands may occur in the axils of other lateral veins; petiole long (and then often varying in length on the same 
leafy twig) or short (and almost equally long on the same leafy twig); stipules semiamplexicaul to lateral, less commonly fully amplexicaul. Figs axillary, ramiflorous, cauliflorous, rarely flagelliflorous; fig receptacle varying from c. 0.3 to c. $2.5 \mathrm{~cm}$ diam. when dry, lateral bracts often present; internal hairs mostly present (abundant to few), less frequently absent; tepals red to whitish, glabrous or hairy (mostly minutely so at the apices). Staminate flowers with small pistillodes. Styles sometimes hairy. Fruits achenes, smooth, weakly tuberculate or finely punctate, mostly \pm distinctly keeled or drupelets with tuberculate endocarp bodies (pyrenes).

Distribution - The section comprises 80-85 species and ranges from Samoa and Australia to Taiwan, Japan, and S China westwards to Réunion, Madagascar, and Africa (westwards to Senegal); in the African region 9 species, in the Pacific region and Australia approx. 22 species, and in Malesia 42 species.

Delimitation - This section is distinct from sect. Palaeomorphe in the absence of adventitious roots, intermittent growth, hollow or solid but much pith containing leafy twigs, the arrangement of leaves spirally alternate, (sub)opposite or subverticillate, absence of unilaterally decurrent base of the lamina, waxy glands at both sides of the midrib, and always small pistillodes in the staminate flowers.

Subdivision - Several groups of evidently or presumably related species can be recognised, but none with clear demarcations. The five (practical and informal) groups of species which can be distinguished are:

1) F. conocephalifolia-group (largely ser. Phaeopilosae Corner (1960b) 445) comprising the species numbered: 3, 5, 6, 11, 26, and 27.

2) F. copiosa-group (largely ser. Copiosae Corner (1960b) 445) comprising the species numbered: $4,7,8,13,17,25,28,34$, and 41 .

3) F. ulmifolia-group (largely ser. Scabrae Miq. (1848) 228 ; Corner (1960b) 445; and subg. Ficus sect. Ficus subsect. Ficus ser. Synosyceae Corner (1960a) 418) comprising the species numbered: $1,9,10,12,14,18,20,21,23,24,29,30,31,33,35,37$, 38,39 , and 40 .

4) F. montana-group (including subsect. Varinga ser. Exasperatae Corner (1960b) 446) comprising the species numbered: 22, 32, and 36.

5) F. heterophylla-group (including subsect. Varinga ser. Heterophyllae and ser. Cyrtophylleae Corner (1960b) 446) comprising the species numbered: 2, 16, and 18.

Note - Ficus tsiangii Merr., the only species included in subg. Ficus sect. Sinosycidium Corner, does not show affinities to any species of the Sino-Himalayan region, but it does to members of the $F$. conocephalifolia-group, although not very clearly. Ficus henryi Diels and F. subincisa Sm., the two species of ser. Sinosyceae can be included in the F. ulmifolia-group.

Malesian species here recognised in sect. Sycidium: 1) F. ampelas Burm.f. (incl. $F$. irisana Elmer, F. guyeri Elmer, F. tenuicuspidata Corner var. major Corner, F. todayensis Elmer; excl. F. ampelas var. linearis Corner); 2) F. asperiuscula Kunth \& C.D. Bouché; 3 ) F. badiopurpurea Diels; 4) F. balica Miq.; 5) F. complexa Corner; 6) F. conocephalifolia Ridl.; 7) F. copiosa Steud.; 8) F.cumingii Miq. (incl. F. ampelas Burm.f. var. linearis Corner, F. chaii Kochummen, 1998, F. fallax Miq.; excl. F. cumingii var. androbrota (Summerh.) Corner); 9) F. elmeri Merr.; 10) F. erinobotrya Corner; 11) F. eustephana Diels; 12) F. fiskei Elmer; 13) F. floresana C.C. Berg (see below); 
14) F. goniophylla Corner; 15) F. gul K. Schum. \& Lauterb. (incl. F. griseifolia Corner); 16) F. heterophylla L.f.; 17) F. heteropoda Miq.; 18) F. leptodictya Diels (=F.tonsa Miq. var. leptodictya (Diels) Corner); 19) F. leptogramma Corner; 20) F. macrorrhyncha K. Schum. \& Lauterb.; 21) F. melinocarpa Blume; 22) F. montana Burm.f. (incl. F. madurensis Miq., F. madurensis Miq. var. angustifolia Corner); 23) F. myiopotamica C.C. Berg (see below); 24) F. odorata (Blanco) Merr.; 25) F. opposita Miq. (incl. F. cumingii Miq. var. androbrota (Summerh.) Corner); 26) F. phaeosyce K. Schum. \& Lauterb.; 27) F. porphyrochaete Corner; 28) F. primaria Corner; 29) F. pseudowassa Corner; 30) F. quercetorum Corner (incl. F. tonsa Miq. var. aspera Corner); 31) F. riedelii Teijsm. ex Miq.; 32) F. sandanakana C.C. Berg (see below); 33) F. schumanniana Warb.; 34) F. sciaphila Corner; 35) F. stellaris C.C. Berg (see below), a) subsp. stellaris, b) subsp.pallida (Corner) C.C. Berg (see below); 36) F. subsidens Corner; 37) F. tenuicuspidata Corner (excl. var. major Corner); 38) F. tonsa Miq. (excl. var. aspera Corner); 39) F. trachypison K. Schum. \& Lauterb. (excl. var. pallida Corner); 40) F. ulmifolia Lam.; 41) F. wassa Roxb. (incl. F. hystricicarpa Warb.). - For other included varieties and synonyms see Corner's check-list (1965: 63-74).

\section{Ficus subg. Sycidium sect. Palaeomorphe King (1887) 1}

Lianas (of the straggling type) or creepers, with short adventitious roots on stems and branches (in touch with the substrate), hemi-epiphytes, or terrestrial shrubs or treelets, with continuous growth. Leafy twigs solid, \pm angular to \pm compressed. Leaves distichously alternate, asymmetric to symmetric, often smooth above, base mostly inequilateral and at one side decurrent and then often auriculate (or lobed); cystoliths only beneath or on both sides; waxy glands mostly in the axils of one of the basal pair, sometimes of both, smaller glands may occur in the axils of other lateral veins, unilaterally or bilaterally; petiole short; stipules semi-amplexicaul or fully amplexicaul. Figs axillary, ramiflorous or cauliflorous; receptacle small, mostly less than $1 \mathrm{~cm}$ diam. when dry; lateral bracts mostly absent; internal hairs mostly absent, if present, then mostly sparse and/or short. Tepals whitish, pinkish or red, glabrous or hairy (mostly minutely so at the apices or along the margins). Staminate flowers with (gall) pistils or (non-functional) pistillodes. Styles sometimes hairy. Fruits achenes, lens-shaped and weekly keeled.

Distribution - The section comprises 30 species, all but one (see Berg, 2000) occurring in the Malesian region, and most of them confined to this region.

Delimitation - For the differences between this section and the typical one see above under sect. Sycidium.

Subdivision - The species can be ranked into two major informal subdivisions:

1) F. subulata-group (ser. Cuspidatae, ser. Fibrosifoliae, ser. Minutiflorae, and ser. Subulatae Corner (1960b) 447-448) comprising the species numbered: 43, 44, 47, $48,49,50,51,52,54,55,56,57,58,59,60,61,62,63,64,65,66,67$, and 69 .

2) F. tinctoria-group (ser. Pallidae Corner (1960b) 447) comprising the species numbered: 42?, 45?, 46, 53, 68, and 70 .

Malesian species here recognised in sect. Palaeomorphe: 42) F. anastomosans Wall. ex Kurz (= F. tinctoria G. Forst. subsp. parasitica (Miq.) Corner var. anastomosans (Wall. ex Kurz) Corner; incl. F. ampelas Burm.f. var. hispidula Corner); 43) F. armitii 
King; 44) F. aurita Reinw. ex Blume; 45) F. cauta Corner; 46) F. celebensis Corner; 47) F. cuspidata Reinw. ex Blume (= F. sinuata Thunb. subsp. cuspidata (Reinw. ex Blume) Corner); 48) F. funiculicaulis C.C. Berg (see below); 49) F. gracillima Diels (=F. subulata Blume var. gracillima (Diels) Corner); 50) F. grewiifolia Blume (=F. obscura Blume var. angustata (Miq.) Corner); 51) F. hemsleyana King; 52) F. heteropleura Blume (excl. var. hirta Corner); 53) F. inaequifolia Elmer (ex synonymy of F. virgata Blume); 54) F. jaheriana Corner; 55) F. kuchinensis C.C. Berg (see below); 56) F. lasiocarpa Miq.; 57) F. leptocalama Corner; 58) F. microsphaera Warb.; 59) F. midotis Corner; 60) F. obscura Blume (incl. F. obscura Blume var. lanata Kochummen, 1998; excl. var. angustata (Miq.) Corner, var. borneensis (Miq.) Corner, var. kunstleri (King) Corner, and var. scaberrima (Blume) Corner); 61) F. parietalis Blume; 62) F. pisifera Wall. ex Voigt (incl. F. obscura Blume var. borneensis (Miq.) Corner and var. kunstleri (King) Corner); 63) F. rubrocuspidata Corner; 64) F. rubromidotis Corner; 65) F. sinuata Thunb. (excl. subsp. cuspidata (Blume) Corner); 66) F. stipata King; 67) F. subulata Blume (excl. var. gracillima (Diels) Corner); 68) F. tinctoria G. Forst., a) subsp. tinctoria (incl. subsp. swinhoei (King) Corner), b) subsp. gibbosa (Blume) Corner (incl. subsp. parasitica (Willd.) Corner, but excl. var. anastomosans (Kurz) Corner); 69) F. uniglandulosa Wall. ex Miq.; 70) F. virgata Reinw. ex Blume (excl. F. inaequifolia Elmer). - For other included varieties and synonyms see Corner's check-list (1965: 64-79).

\section{NEW SPECIES, SUBSPECIES, AND COMBINATIONS}

Ficus floresana C.C. Berg, spec. nov. - Fig. 1

Fico balicae similis, ab ea lamina minore basi rotundata ad cuneata, venis lateralibus basalibus simplicicibus differt. - Typus: Verheijen 1645 (holo L), Indonesia, Flores, Ruteng, 1660 m, 4 May 1967.

Tree (medium-sized?). Leafy twigs $1.5-2.5$ thick, very sparsely whitish minutely subhispidulous to (sub) glabrous, smooth; internodes solid or hollow. Leaves in lax spirals, sometimes (sub)opposite; lamina oblong, $7-12.5$ by $2.5-4.5 \mathrm{~cm}$, slightly asymmetric or to almost symmetric, subcoriaceous, apex acuminate to subacute, base rounded to cuneate, margin entire, flat; both surfaces glabrous, smooth; cystoliths on both sides; lateral veins $6-8(-9)$ pairs, the basal pair running close to the margin, unbranched, up to $1 / 5-1 / 3$ the length of the lamina, unbranched, the other lateral veins sometimes furcate, tertiary venation subscalariform to reticulate; waxy glands in the axils of both basal pair; petiole $0.8-4.5 \mathrm{~cm}$ long, clearly different to almost equal in length on the same twig, (very) sparsely puberulous to glabrous, epidermis flaking off; stipules lateral to semi-amplexicaul, subovate, chartaceous, c. $0.5 \mathrm{~cm}$ long, ciliolate, caducous. Figs axillary, solitary; peduncle $0.8-2.3 \mathrm{~cm}$ long; peduncular bracts 2 or 3 , scattered, 0.5 $\mathrm{mm}$ long; receptacle (sub)globose to ellipsoid, $0.5-1.3 \mathrm{~cm}$ diam. when dry, sparsely hispidulous or glabrous, scabridulous or smooth, with few $0.5-1 \mathrm{~mm}$ long lateral bracts or none, colour at maturity unknown, apex \pm convex to umbonate, ostiole $1.5-2.5 \mathrm{~mm}$ diam., \pm sunken or surrounded by a low rim; internal hairs minute, few. Tepals red (dark brown when dry), (sparsely) hairy at the apices. Styles sparsely hairy.

Distribution - Lesser Sunda Islands (Flores, endemic). 


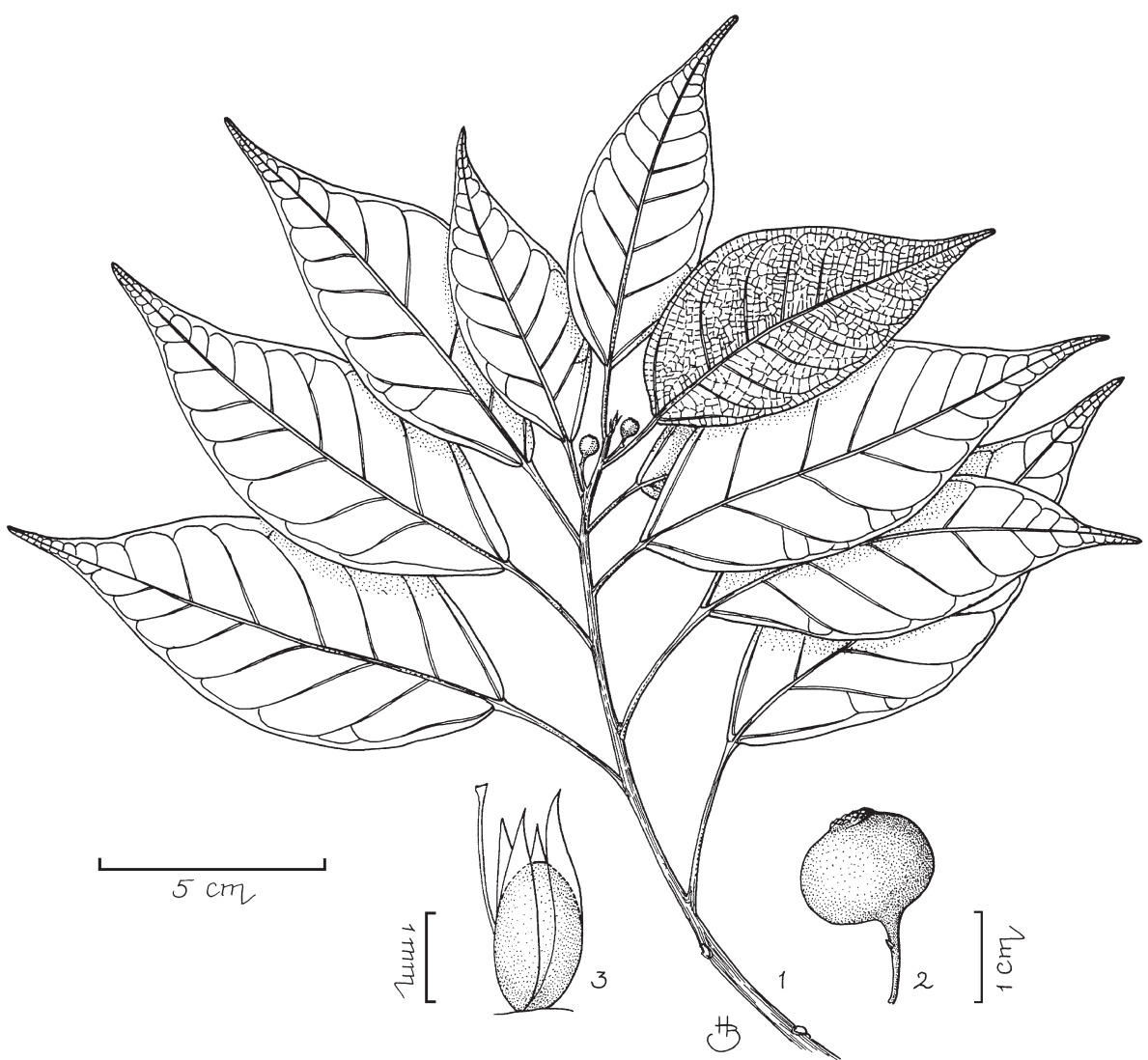

Fig. 1. Ficus floresana C.C. Berg. 1. Leafy twigs with young figs; 2. fig; 3. long-styled pistillate flower (1: Schmutz, 2710; 2, 3: Verheyen 1646).

Habitat - Monsoon forest; at altitudes up to $1660 \mathrm{~m}$.

Notes -1 . Some collections of this species have been identified by Corner as F. leptoclada Benth. from Australia. But they certainly do not belong to that species and they could not be accommodated in any other species. Considering the similarities of the flowers, this new species is related to F. balica, from which it differs in the smaller laminas with a rounded to cuneate base.

2. The description is also based on Schmutz, 2710 (L), Verheijen 1646 (L) and Verheijen $2673(\mathrm{~L})$.

Ficus funiculicaulis C.C. Berg, spec. nov. - Fig. 2

Fico armitii et $F$. gracillimae similis, inflorescentiis flagelliflores, lamina cystolithis ambobus lateralibus distincta. - Typus: Sands, Pattison \& Wood 1457 (holo L), Papua New Guinea, Subprov. Kikori, c. 208 km upstream from coast on the Purari river, about $8 \mathrm{~km}$ upstream from Waado to south of the Pikae river, 7 N 03' S, 144 N 58' E, $130 \mathrm{~m}$, 20 Aug. 1975. 


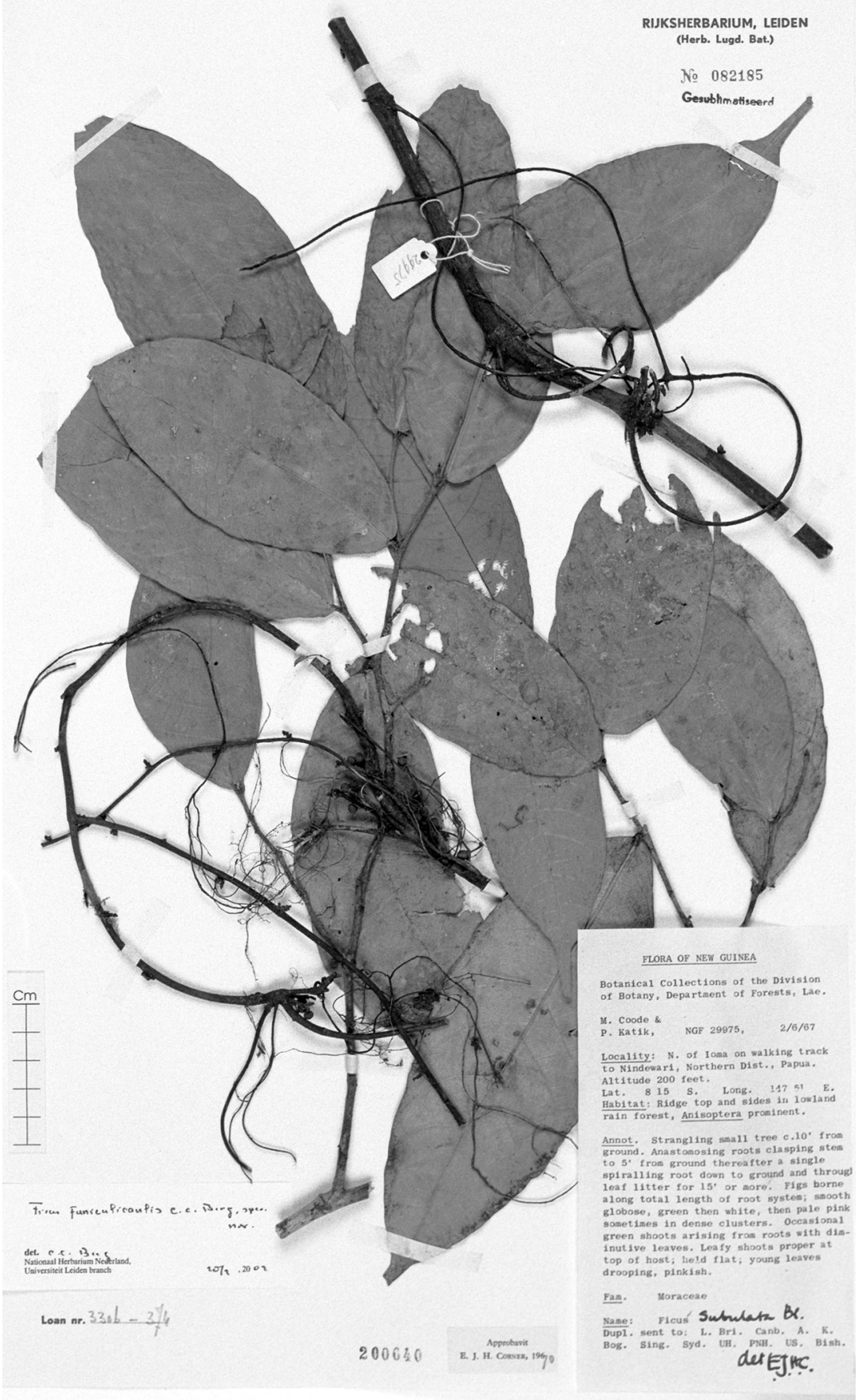

Fig. 2. Ficus funiculicaulis C.C. Berg. Leafy twigs and fig-bearing leafless branchlets (M. Coode \& P. Katik NGF 29975, L), Papua New Guinea, Northern Province, N of Ioma, 2 June 1967. 
Liana, and/or (pesudo- or hemi-?)epiphytic treelet up to $3 \mathrm{~m}$ tall with clasping aerial roots. Branchlets drying brown to greyish, fig-bearing branchlets to blackish. Leafy twigs 1.5-2 mm thick, (very) sparsely puberulous to subhispidulous, (almost) smooth. Leaves distichously alternate; lamina oblong to subobovate, $6-19$ by $2-7 \mathrm{~cm}$, somewhat asymmetric to almost symmetric, subcoriaceous to chartaceous, apex acuminate to subcaudate, base \pm inequilateral to almost equilateral, if inequilateral, then one side cuneate (to subcordate), the other side slightly to clearly decurrent, auriculate or not, if equilateral, then subcordate, margin entire, flat; both surfaces glabrous, smooth; cystoliths on both sides; midrib prominent above; lateral veins 7-10(-11) pairs, the basal pair up to 1/10-1/4 the length of the lamina, unbranched, usually 1-3 pairs of smaller subbasal lateral veins, the other lateral veins also unbranched, tertiary venation laxly scalariform; waxy glands in the axils of one of the basal lateral vein; petiole 0.1-0.4 $\mathrm{cm}$ long, (very) sparsely whitish puberulous, epidermis flaking off; stipules amplexicaul, $0.2-1 \mathrm{~cm}$ long, sparsely and minutely whitish appressed-puberulous to glabrous, caducous. Figs flagelliflorous, on (clusters of) up to $1 \mathrm{~cm}$ long leafless branchlets with short internodes on up to c. $5 \mathrm{~m}$ long stolons; peduncle $0.2-0.5 \mathrm{~cm}$ long; peduncular bracts 1 or 2 (or 3), scattered, c. $0.5 \mathrm{~mm}$ long, ovate; receptacle (sub)globose to ovoid, $0.2-0.3 \mathrm{~cm}$ diam. when dry, glabrous, smooth, without lateral bracts, colour at maturity unknown, apex convex to slightly umbonate, ostiole $0.5-1 \mathrm{~mm}$ diam., surrounded by a very low irregular rim, the outer ostiolar slightly protruding; internal hairs absent. Tepals reddish (brownish when dry), glabrous. Styles glabrous.

Distribution - New Guinea (eastern).

Habitat \& Ecology - Rain forest; at low altitudes.

Notes -1 . This species can be distinguished from the other small-leaved species of sect. Palaeomorphe found in New Guinea, F. armitii and F. gracillima, by flagelliflory and the presence of cystoliths on both sides of the lamina.

2. According to the label data the figs are born on pendulous, rope-like, leafless, rooting branches extending as stolons in the litter. These branches depart from lianescent stems or stems of epiphytes attached to the stem of the host tree up to $1.5 \mathrm{~m}$ from the forest floor. From these branches occasional shoots with diminutive leaves arise.

3. The description is also based on Coode \& Katik NGF 29975 (L) and Schodde \& L.A. Craven 4440 (L).

Ficus kuchinensis C.C. Berg, spec. nov.

Based on: Ficus heteropleura Blume var. hirta Corner (1960b) 480. - Type: Bureau of Science (Manila), 'Native collectors No. 1938' (holo L), Malaysia, Sabah.

Treelet up to $5 \mathrm{~m}$ or climber. Branchlets drying dark brown to purplish. Leafy twigs 1.5-2.5 mm thick, densely brown puberulous to subhirtellous, smooth; internodes solid. Leaves distichously alternate; lamina oblong (to elliptic), 7-20 by $2-6 \mathrm{~cm}$, (almost) symmetric to \pm asymmetric, (sub)coriaceous, apex caudate, base (almost) equilateral, rounded to obtuse, margin entire or on one or both sides irregularly coarsely dentate to sublobate, often \pm revolute; upper surface glabrous, smooth, mostly shiny, lower surface \pm densely puberulous to subtomentose on the veins, smooth; cystoliths only beneath; midrib impressed above, lateral veins 4-7 pairs, the basal pair running close to the margin of the lamina, up to $1 / 3-1 / 2$ the length of the lamina, unbranched, the 
other lateral veins often branched or furcate, tertiary venation laxly (sub)scalariform to reticulate; waxy glands in the axils of one of the basal pair; petiole $0.3-0.6 \mathrm{~cm}$ long, densely brown puberulous to subtomentose, epidermis persistent; stipules semiamplexicaul, 0.4-0.8 cm long, brown puberulous to substrigillose, striate, subpersistent. Figs axillary or just below the leaves, in pairs or solitary; peduncle $0.1-0.2 \mathrm{~cm}$ long; peduncular bracts 2 or 3 , scattered, most at the base, c. $0.5 \mathrm{~mm}$ long; receptacle (sub) globose, $0.3-0.5 \mathrm{~cm}$ diam. when dry, \pm densely hispidulous, often scabridulous, without lateral bracts, at maturity pink to red, apex umbonate, ostiole c. $1 \mathrm{~mm}$ diam., sunken, surrounded by a rim; internal hairs absent. Tepals whitish to pinkish (pale brown when dry), glabrous. Styles glabrous.

Distribution - Borneo (Kalimantan, Sabah, and Sarawak).

Habitat - Forest; at low altitudes.

Notes -1 . This species resembles $F$. heteropleura and has been described as var. hirta of that species (Corner, 1960b). However, the differences found justify recognition of a distinct species. The important differences are: the persistent epidermis of the petiole, the subpersistent stipules, the small figs with a very short peduncle and an umbonate apex with a sunken ostiole.

2. The description is also based on Anderson 9147 (L), 'B.6.F.R' KEP 80038 (L), Banyeng ak Nudong et al. S 24942 (L) Bobeng b. Sitam S 14646 (L), Church et al. 525 (L), Dewol Sundaling SAN 78300 (L), Saikeh Lantho SAN 72213 (L), Sibat ak Luang et al.S $25236(\mathrm{~L})$.

Ficus myiopotamica C.C. Berg, spec. nov. - Fig. 3

Fico melinocarpae similis, e.g. in stipulis semi-amplexicaulibus, pilis non nisi in et secus petioli sulcum adaxialum distincta. - Typus: Brass 8079 (holo L), Papua New Guinea, Lower Fly River, opposite Sturt Island, Oct. 1936.

Tree up to $40 \mathrm{~m}$ tall, with buttresses. Branchlets drying blackish. Leafy twigs 2-4 mm thick, glabrous, (almost) smooth; internodes solid. Leaves distichously alternate; lamina elliptic (to suborbicular), 7-17 by $4.5-10 \mathrm{~cm}, \pm$ asymmetric, (sub)coriaceous, apex subacute, base \pm inequilateral, rounded to subcordate, margin subentire, slightly revolute; upper surface sparsely and minutely puberulous at the base (or lower part) of the midrib, smooth, lower surface glabrous (almost); cystoliths on both sides; the base (or lower part) of the midrib impressed, lateral veins 6-12 pairs, the basal pair up to $1 / 4-1 / 3$ the length of the lamina, these and mostly also other lateral veins branched or furcate, tertiary venation scalariform, slightly prominent but the smaller veins to almost flat beneath; waxy glands in the axils of both basal pair; petiole 1.5-1.8 cm long, almost equal in length on the same twig, sparsely and minutely puberulous in and along the adaxial groove of the petiole, epidermis persistent; stipules semi-amplexicaul, 0.3-0.4 $\mathrm{cm}$ long, ciliolate, caducous. Figs axillary, in pairs or solitary; peduncle $0.4-0.5 \mathrm{~cm}$ long; peduncular bracts 3 , verticillate (subtending the receptacle or on the basal part of the receptacle), 0.5-1.5 $\mathrm{mm}$ long; receptacle (sub)globose, c. $1 \mathrm{~cm}$ diam. when dry, glabrous, punctate, smooth, without lateral bracts, at maturity yellow to orange, apex convex, ostiole 1-1.5 mm diam., surrounded by a low rim; internal hairs rather abundant. Tepals pale red, glabrous. Styles glabrous. Fruits tuberculate.

Distribution - New Guinea (eastern).

Habitat - Forest (on riverbanks); at low altitudes. 


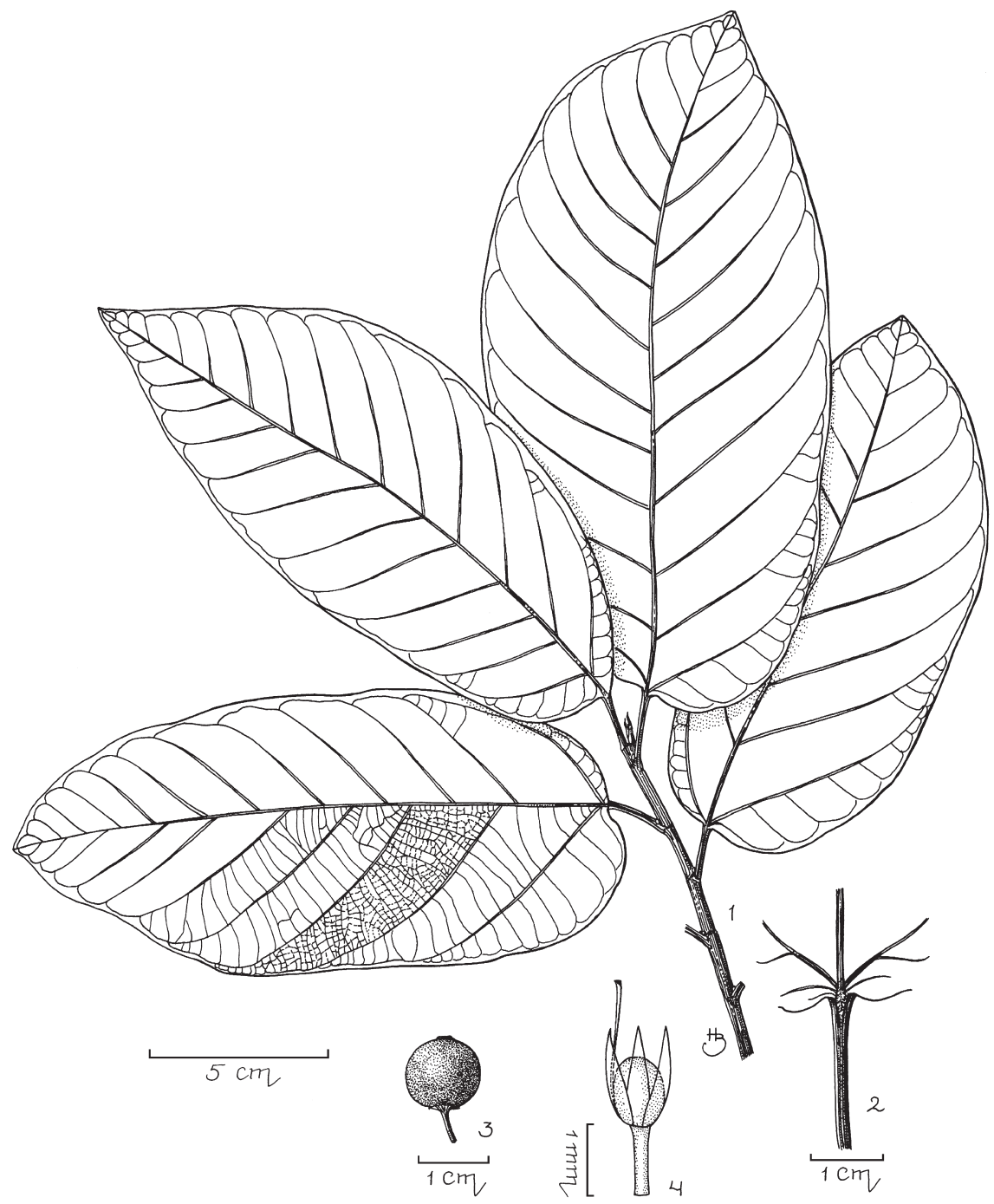

Fig. 3. Ficus myiopotamica C.C. Berg. 1. Leafy twig; 2. groove of the petiole with hairs; 3. fig; 4. long-styled pistillate flower (all Brass 8079)

Notes -1 . The material here described, has been included in F. melinocarpa, from which it differs in the semi-amplexicaul stipules and in being glabrous on nearly all parts, except for the margins of the stipules and in and along the adaxial groove of the petiole and the basal part of the midrib, which is clearly impressed.

2. This species shows affinities to F. leptodictya, also glabrous on the various parts, but with usually a cuneate to obtuse base of the lamina and the basal lateral veins usually running close to the margin and then unbranched.

3. The description is also based on Womersley $4630(\mathrm{~L})$. 


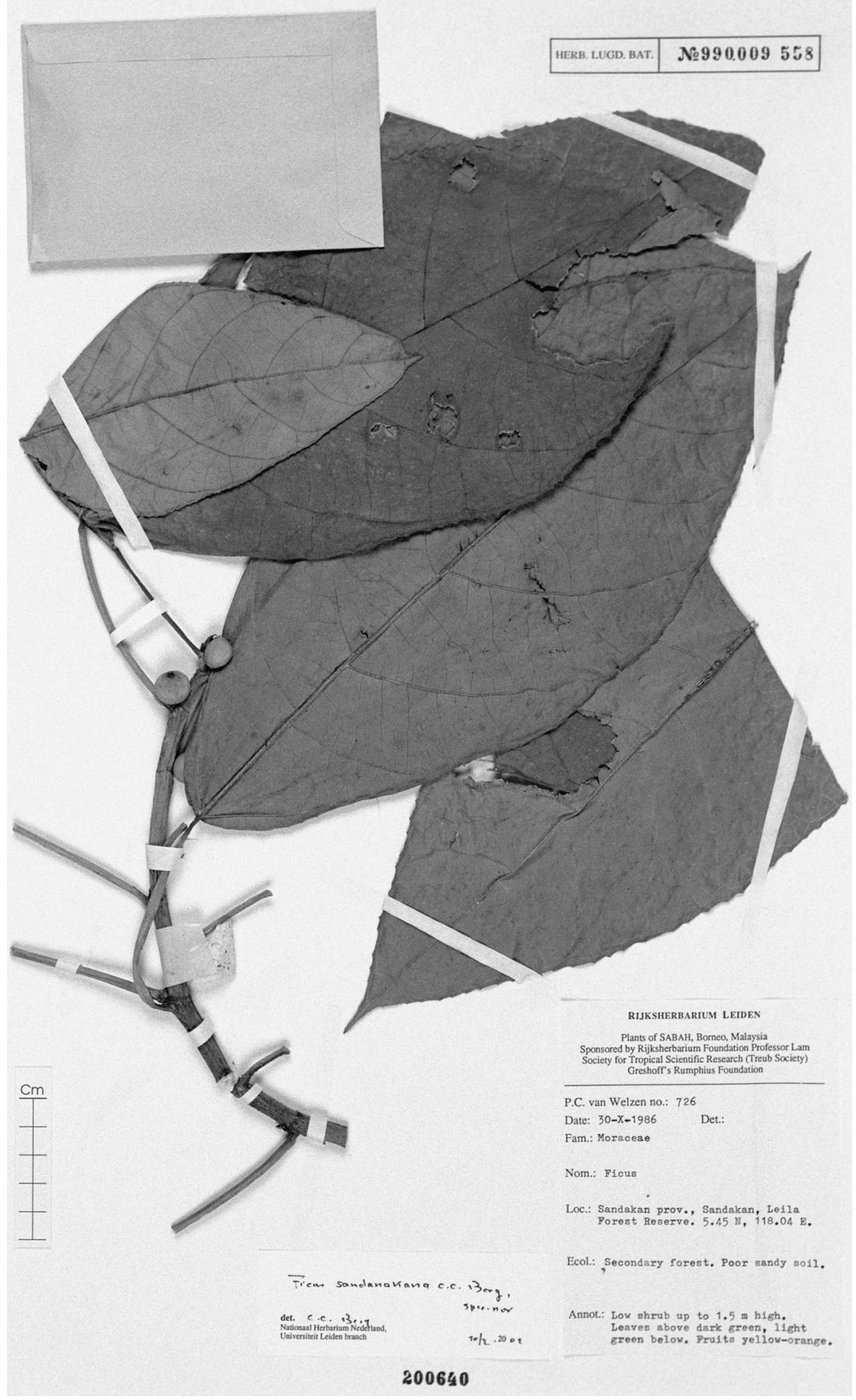

Fig. 4. Ficus sandanakana C.C. Berg. Leafy twig with figs (Van Welzen 726, L), Malaysia, Sabah, Sandakan, Laila Forest Reserve, 30 Oct. 1986. 
Ficus sandanakana C.C. Berg, spec.nov. - Fig. 4

Fico montanae similis, e.g. syconiis (sub)sessilibus, laminae margine regulaliter dentata distincta. - Typus: Van Welzen 726 (holo L), Malaysia, Sabah, Sandakan District, Sandakan, Leila Forest Reserve, 30 Oct. 1986.

Shrub up to $1.5 \mathrm{~m}$ tall or treelet. Leafy twigs (1.5-)3-6 mm thick, brownish hispidulous; internodes hollow. Leaves spirally alternate; lamina oblong to lanceolate to linear-lanceolate, $6-29$ by $1.5-12 \mathrm{~cm}$, (almost) symmetric, chartaceous, apex acuminate, base rounded to obtuse, margin denticulate; upper surface brownish hispidulous, mainly on the veins, scabrous, lower surface brownish hispidulous, scabrous; cystoliths on both sides, sparse; lateral veins $6-9(-16)$ pairs, the basal pair up to $1 / 10-1 / 4$ the length of the lamina, often branched in broad laminas, tertiary venation laxly scalariform or subreticulate in narrow leaves; waxy glands in the axils of both basal pair or also smaller ones in the axils of other lateral veins; petiole 1-9 cm long, slightly different to almost equal in length on the same twig, sparsely brownish hispidulous, epidermis persistent; stipules semi-amplexicaul, $0.7-1 \mathrm{~cm}$ long, brownish strigillose, caducous . Figs in the leaf axils, paired or solitary, subsessile or sessile; peduncular bracts 1-3,2-3 $\mathrm{mm}$ long; receptacle (sub) globose, $0.8-1.2 \mathrm{~cm}$ diam. when dry, sparsely hispidulous, scabridulous, without lateral bracts, at maturity orange, apex \pm convex to umbonate, ostiole 1-1.5 mm diam., surrounded by c. 5 brown hairy apical bracts; internal hairs abundant, white, up to $1.5 \mathrm{~mm}$ long. Tepals whitish, conspicuously hairy, the hairs up to $1.5 \mathrm{~mm}$ long. Styles glabrous. Fruits (endocarp body) 1-1.5 mm long, subtetrahedral, tuberculate, weakly keeled.

Distribution - Borneo (northern: Sandakan District).

Habitat - Secondary growth; at low altitudes.

Notes -1 . This species is closely related to $F$. montana (which also occurs in $\mathrm{N}$ Borneo). It differs from the widespread $F$. montana in the thicker leafy twigs, the brownish indumentum on the various plant parts, the more finely and regularly dentate margin of the lamina, the (sub)sessile figs with relatively large penduncular (or basal) bracts (2-3 mm long), and in particular the conspicuously hairy inner surface of the fig receptacle and the hairy tepals.

2. The description is also based on Dewol et al. SAN 74264 (L).

Ficus stellaris C.C. Berg, spec.nov. - Fig. 5

Fico trachypisoni similis, ab ea e.g. in glandulis ceraceis non nisi in venarum lateralium axillis basalibus, et Fico melinocarpae, ab ea e.g. in stipulis semi-amplexicaulibus differt. - Typus: Vinas et al. LAE 59552 (Star Mountains expedition) (holo LAE; iso $\mathrm{L}$, according to the label duplicates also in A, BISH, BO, BRI, CANB, K, PNH, SING, SYD, US), Papua New Guinea, Prov. West Sepik, Subprov. Telefomin, Folongonom, 2300 m, 20 May 1975.

Tree up to 20(-40) $\mathrm{m}$ tall (or shrub). Branchlets drying dark (red-)brown to blackish. Leafy twigs 1.5-2.5 mm thick, minutely whitish hispidulous, scabrous; internodes solid or hollow. Leaves distichously alternate; lamina elliptic to ovate, 2-12(-16) by $2-7(-8) \mathrm{cm}, \pm$ asymmetric, (sub)coriaceous, apex acuminate to subacute, base \pm inequilateral, truncate (to subcordate) to subcuneate, margin irregularly crenatedent(icul)ate to subentire, usually \pm revolute; upper surface minutely hispidulous, 


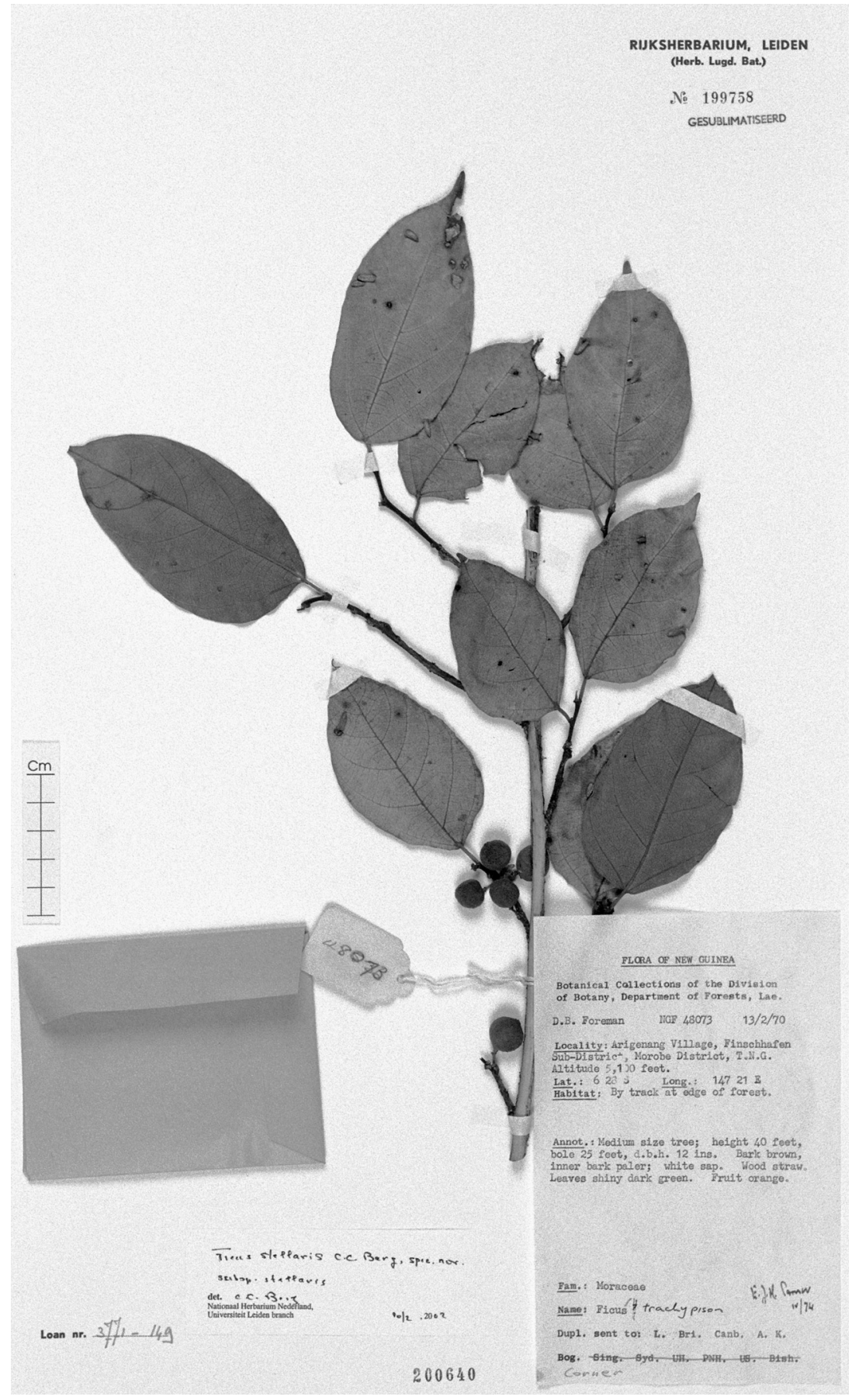

Fig. 5. Ficus stellaris C.C. Berg subsp. stellaris. Leafy twigs with figs (D.B. Foreman NGF 48073, L), Papua New Guinea, Morobe Province, Arigenang, 13 Feb. 1970. 
scabrous, lower surface minutely hispidulous on the veins, or also very sparsely strigillose on the midrib, scabrous; cystoliths on both sides; lateral veins 3-7(-9) pairs, the basal pair up to $1 / 4-1 / 2$ the length of the lamina, these and mostly also other lateral veins branched or furcate, tertiary venation scalariform, slightly prominent but the smaller veins to almost flat beneath; waxy glands in the axils of both basal pair; petiole $0.5-1.5(-2) \mathrm{cm}$ long, slightly different to almost equal in length on the same twig, minutely hispidulous, epidermis persistent; stipules semi-amplexicaul, 0.4-0.6 $\mathrm{cm}$ long, minutely hispidulous and ciliolate, caducous. Figs axillary or just below the leaves, solitary or in pairs; peduncle $0.2-1 \mathrm{~cm}$ long; peduncular bracts 3 , scattered or verticillate, $1-2 \mathrm{~mm}$ long; receptacle (sub)globose, $0.3-0.6$ or (0.5-) $0.7-1.2 \mathrm{~cm}$ diam. when dry, minutely hispidulous, scabridulous, often with few $0.5-1 \mathrm{~mm}$ long lateral bracts, at maturity yellow to orange, apex convex, ostiole 1.5-3 mm diam., surrounded by a low rim; internal hairs abundant. Tepals dark red or pinkish, hairy at the apices or glabrous. Styles glabrous or hairy. Fruits \pm tuberculate.

Distribution - New Guinea.

Notes -1 . This species has been confused with both F. trachypison and F. melinocarpa. It can be distinguished from the former by the absence of additional waxy glands in the axils of lateral veins others than the basal ones and the relatively large figs and from the latter by the semi-amplexicaul stipules and the always scabrous lower and upper surface of the lamina.

2. This species also shows similarities to F. leptodictya and F. pseudowassa.

3. Two subspecies can be distinguished.

\section{a. subsp. stellaris}

Figs mostly in the leaf axils, the receptacle relatively large (usually $0.7-1.2 \mathrm{~cm}$ diam. when dry), and the peduncle relatively long $(0.2-1 \mathrm{~cm})$. Tepals dark red and glabrous.

Distribution - New Guinea (eastern).

Habitat - Forest (as oak forest); at altitudes between 1200 and $2300 \mathrm{~m}$.

Note - The descriptions of the species and subspecies are also based on Carr 16075 (L), Clemens 7366 (L), Foreman NGF 48073 (L), Jacobs 8725 (L), Schodde 1410 (L), Schodde et al. 5087 (L), Stevens LAE 54812, and Womersley 4863 (L).

b. subsp. pallida (Corner) C.C. Berg, comb. \& stat. nov.

Based on: Ficus trachypison K. Schum. var. pallida Corner (1960b) 462. - Type: Brass 25364 (holo A), Papua New Guinea, Normanby Island, Waikaiuna, 20 m, 11 April 1956.

Figs mostly below the leaves, the receptacle small $(0.3-0.6 \mathrm{~cm}$ diam. when dry) and the peduncle $0.2-0.3 \mathrm{~cm}$ long. Tepals pinkish and hairy.

Distribution - New Guinea (eastern).

Habitat - River banks (as bushy tree), river beds (as shrub), rocky surfaces, or forest pockets in grassland; at altitudes up to $100 \mathrm{~m}$.

Note - The descriptions of the species and subspecies are also based on Brass 8895 (L), Darbyshire 595 (L), Floyd et al. 3828 (L), Gillison NGF 22355 (L), Mann et al. NGF 43011 (L), and Streimann NGF 45118 (L). 


\section{KEY TO THE MALESIAN SPECIES OF SUBGENUS SYCIDIUM}

1a. Leaves spirally alternate or partly (sub)opposite, sometimes subverticillate .. 2

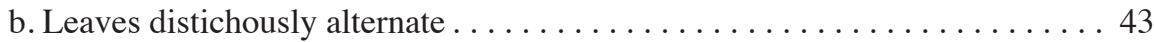

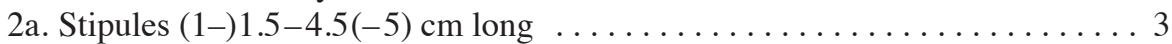

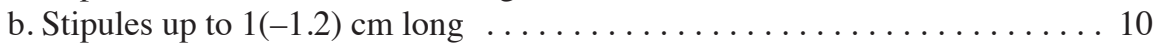

3a. Leafy twigs (sparsely) whitish hispidulous, (densely) whitish puberulous or hirtellous, or glabrous; stipules caducous (or only persistent in tufts at the apices of

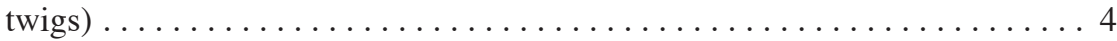

b. Leafy twigs at least partly (dark) brown hirsute to hirtellous or strigose to strigil-

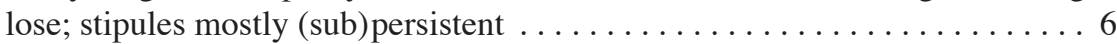

4a. Epidermis of the petiole persistent; fig receptacle longer than wide, $2-2.5 \mathrm{~cm}$

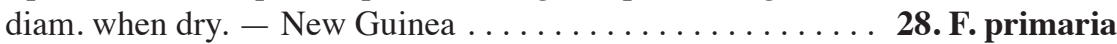

b. Epidermis of the petiole flaking off over the whole length or only at the basal and upper part; fig receptacle about as long as wide, or if longer than wide, then up to

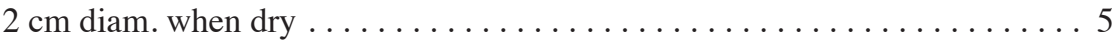

5a. Lateral veins (4-)6-10 pairs; petiole $1.5-3 \mathrm{~mm}$ thick, its epidermis flaking off at the basal and upper part. - Sulawesi, Moluccas, New Guinea . 7. F. copiosa

b. Lateral veins (8-)10-12 pairs; petiole (2-)3-5 mm thick, its epidermis flaking off over the whole length. - New Britain and New Ireland . . 34. F. sciaphila

6a. Lateral bracts of the fig receptacle 5-20 mm long, often numerous and largely or

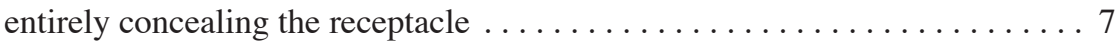

b. Lateral bracts of the fig receptacle to $5 \mathrm{~mm}$ long, several, few, or none . . . . 8

7a. Petiole (1.5-)4-15(-20) cm long; base of the lamina (sub)cordate. - New

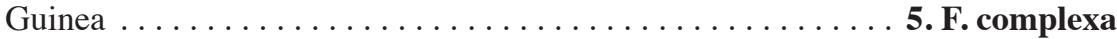

b. Petiole $1-5.5 \mathrm{~cm}$ long; base of the lamina rounded. - New Guinea . . . . . . . .

11. F. eustephana

8a. Petiole $0.4-1(-1.5) \mathrm{cm}$ long, slightly different to almost equal in length on the

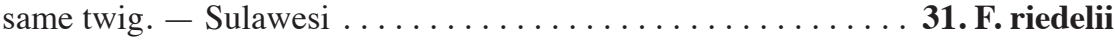

b. Petiole $0.5-12(-30) \mathrm{cm}$ long, distinctly different in length on the same twig . 9

9a. Basal lateral veins up to $1 / 4-1 / 3$ the length of the lamina; fig receptacle $0.7-1.5$ cm diam. when dry. - New Guinea . . . . . . . 27. F. porphyrochaete

b. Basal lateral veins up to $1 / 3-1 / 2(-2 / 3)$ the length of the lamina; fig receptacle $(1-) 1.5-2(-3) \mathrm{cm}$ diam. when dry. - New Guinea .. . 6. F. conocephalifolia

10a. Hairs (partly) uncinate. - Sumatra and Java . . . . . . 2. F. asperiuscula

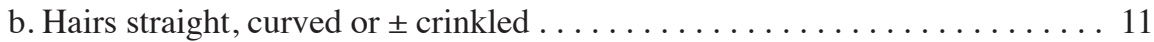

11a. Leafy twigs and lower surface of the lamina (at least partly) with (dark) brown

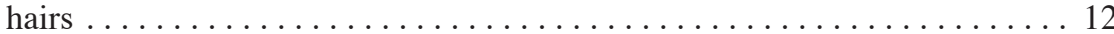

b. Leafy twigs and lamina beneath with whitish hairs or indumentum absent . . 17

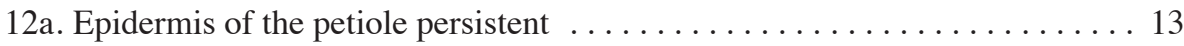

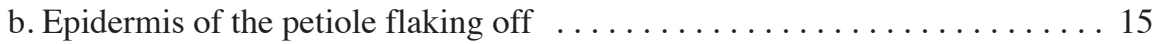

13a. Basal lateral veins up to $1 / 3-1 / 2$ the length of the lamina; petiole $0.4-1(-1.5) \mathrm{cm}$ long, slightly different to almost equal in length on the same twig. - Sulawesi

31. F. riedelii

b. Basal lateral veins up to $1 / 5-1 / 3$ the length of the lamina; petiole $(0.5-) 1-8(-12)$ $\mathrm{cm}$ long, distinctly different in length on the same twig . . . . . . . . 14 
14a. Waxy glands on the lamina absent; figs cauliflorous to flagelliflorous on leafy branches on the trunk or on up to $3 \mathrm{~m}$ long stolons. - New Guinea

3. F. badiopurpurea

b. Waxy glands on the lamina present, conspicuous, largely on the midrib; figs axillary to cauliflorous. - Borneo, Philippines, Sulawesi, Lesser Sunda Islands,

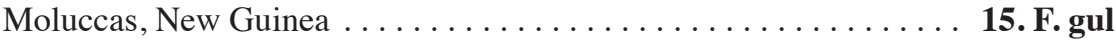

15a. Basal lateral veins up to $1 / 3-1 / 2$ the length of the lamina; fig receptacle $1.3-1.8$ $\mathrm{cm}$ diam. when dry, with numerous up to $15 \mathrm{~mm}$ long lateral bracts. - New

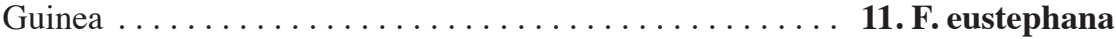

b. Basal lateral veins up to $1 / 8-1 / 3$ the length of the lamina; fig receptacle $0.4-0.8$ $(-1.2) \mathrm{cm}$ diam. when dry, with few up to $3 \mathrm{~mm}$ long lateral bracts . . . . 16

16a. Waxy glands on the lamina absent; basal lateral veins up to $1 / 8-1 / 6$ the length of the lamina and unbranched. - New Guinea ......... 26. F. phaeosyce

b. Waxy glands on the lamina present, conspicuous, largely on the midrib; basal lateral veins up to $1 / 4(-1 / 3)$ the length of the lamina and mostly branched. - Borneo, Philippines, Sulawesi, Lesser Sunda Islands, Moluccas, New Guinea .15. F. gul

17a. Leafy twigs and laminas glabrous and (almost) smooth . . . . . . . . . 18

b. Leafy twigs and laminas (densely or sparsely) hairy and/or scabrous to scabridu-

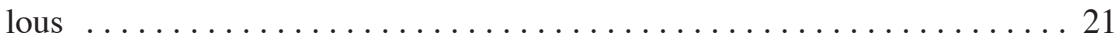

18a. Additional waxy glands present in the axils of other lateral veins than the basal ones; leaves distinctly arranged spirally alternate. - Lesser Sunda Islands, Moluc-

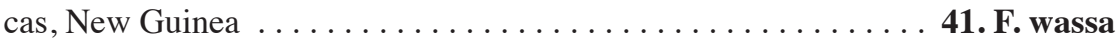

b. Additional waxy glands absent; leaves arranged in lax spirals to distichously alternate, rarely opposite . . . . . . . . . . . . . . . . . . . 19

19a. Shrubs up to $3 \mathrm{~m}$ tall, often prostrate. - Malay Peninsula, Java, Borneo . . . . .

16. F. heterophylla

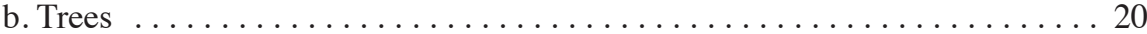

20a. Apex of the lamina shortly and \pm abruptly acuminate to rounded; margin of the lamina usually \pm revolute. - Sulawesi . . . . . . . . . . 38. F. tonsa

b. Apex of the lamina (sub)acuminate to subacute; margin of the lamina flat. - New Guinea ...................... Ieptodictya

21a. Basal lateral veins up to $1 / 3-1 / 2$ the length of the lamina . . . . . . . 22

b. Basal lateral veins up to $1 / 20-1 / 3$ the length of the lamina . . . . . . . 23

22a. Petiole 2-9 cm long, varying considerably in length on the same twig; peduncle 1-5 cm long, the ostiole surrounded by a low rim. - Philippines, Sulawesi,

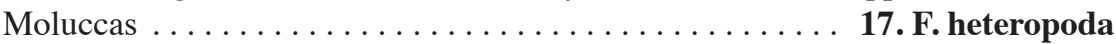

b. Petiole $0.5-3 \mathrm{~cm}$ long, varying slightly to almost equal in length on the same twig; peduncle $0.2-1.5 \mathrm{~cm}$ long, the ostiole surrounded by apical bracts, these as well as the narrow outer ostiolar bracts pointing upwards. - Philippines . . . . .

40. F. ulmifolia

23a. Epidermis of the petiole flaking off over the whole length or only at the basal part

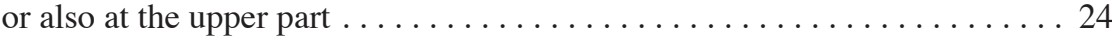

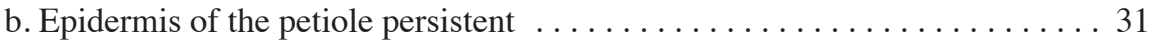

24a. Waxy glands on the midrib and nearly fused. - New Guinea . . . . 15. F. gul

b. Waxy glands in the axils of the basal lateral veins $\ldots \ldots \ldots \ldots \ldots \ldots 25$ 


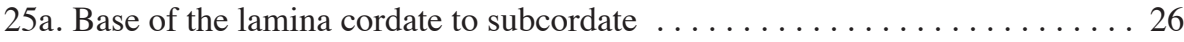

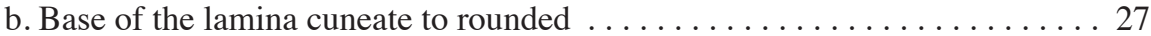

26a. Stipules c. $0.5 \mathrm{~cm}$ long, subovate, chartaceous. - Java, Lesser Sunda Islands . .

4. F. balica

b. Stipules 0.5-2 cm long, almost subulate, coriaceous. - Sulawesi, Moluccas, New

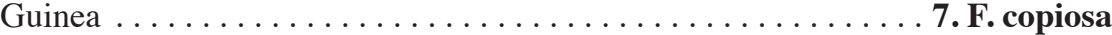

27a. Petiole 1-9.5 cm long, on the same twig usually considerably different in length

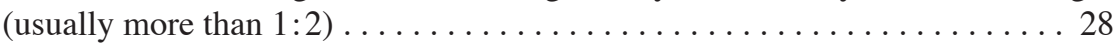

b. Petiole $0.5-2(-4.5) \mathrm{cm}$ long, on the same twig slightly different in length (usually

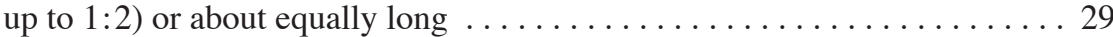

28a. Stipules 0.5-2 cm long, almost subulate, coriaceous. - Sulawesi, Moluccas, New

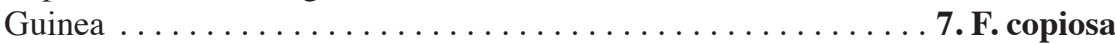

b. Stipules c. $0.5 \mathrm{~cm}$ long, subovate, chartaceous. - Flores . . . 13. F. floresana

29a. Stipules almost subulate and finely striate, often subpersistent (at least at the apices of leafy twigs); figs mostly ramiflorous to cauliflorous, in clusters. - Lesser Sunda Islands, Moluccas, New Guinea . . . . . . . . . . . 41. F. wassa

b. Stipules subovate to lanceolate and chartaceous, not striate, caducous; figs axillary or just below the leaves, in pairs or solitary $\ldots \ldots \ldots \ldots \ldots \ldots \ldots \ldots \ldots$

30a. Figs sessile or with a peduncle up to $0.3 \mathrm{~cm}$ long. $-\mathrm{N}$ Borneo, Philippines, Sulawesi

b. Figs with a peduncle $0.8-2.3 \mathrm{~cm}$ long. - Flores . . . . . 13. F. floresana

31a. Waxy glands on, or largely on, the midrib; base of the lamina mostly cordate to

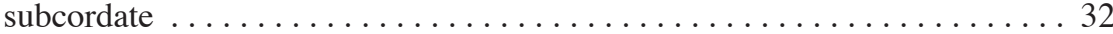

b. Waxy glands confined to the axils of the basal lateral veins; base of the lamina

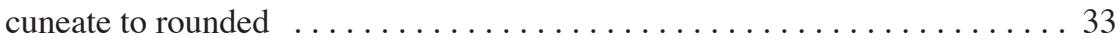

32a. Fig receptacle longer than wide, $2-2.5 \mathrm{~cm}$ diam. when dry. - New Guinea ...

28. F primaria

b. Fig receptacle subglobose, $0.3-1.2 \mathrm{~cm}$ diam. when dry. - Borneo, Philippines, Sulawesi, Lesser Sunda Islands, Moluccas, New Guinea . . . . . . . 15. F. gul

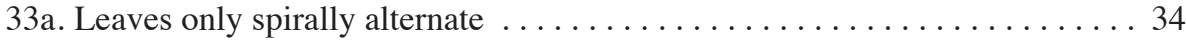

b. Leaves at least partly (sub)opposite or subverticillate ............. 41

34a. Stipules almost subulate and finely striate, often subpersistent (at least at the apices of leafy twigs); figs mostly ramiflorous to cauliflorous, in clusters. - Lesser Sunda Islands, Moluccas, and New Guinea . . . . . . . . . 41. F. wassa

b. Stipules subovate to lanceolate and chartaceous, not striate, caducous; figs axillary or just below the leaves, in pairs or solitary $\ldots \ldots \ldots \ldots \ldots \ldots \ldots \ldots$

$35 \mathrm{a}$. Basal lateral veins up to $1 / 10-1 / 20$ the length of the lamina; lamina linear-lan-

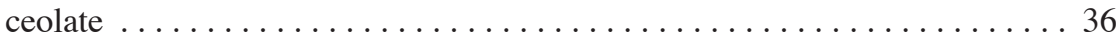

b. Basal lateral veins up to $1 / 6-1 / 3$ the length of the lamina; lamina oblong to el-

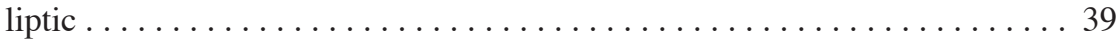

36a. Leafy twigs solid; lamina (sub)coriaceous; figs sessile or with a peduncle up to $0.3 \mathrm{~cm}$ long. - N Borneo, Philippines, Sulawesi . . . . . . 8. F. cumingii

b. Leafy twigs usually hollow; lamina chartaceous; figs usually with a peduncle

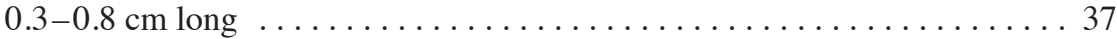

37a. Indumentum of leafy twig, petiole, and lamina beneath brownish; figs (sub)sessile, the receptacle $0.8-1.2 \mathrm{~cm}$ diam. when dry. $-\mathrm{N}$ Borneo . . 32. F. sandanakana 
b. Indumentum of leafy twig, petiole, and lamina beneath whitish (and sparse); figs with a distinct peduncle, $(0.1-) 0.2-0.8 \mathrm{~cm}$ long, the receptacle $0.5-0.8 \mathrm{~cm}$ diam.

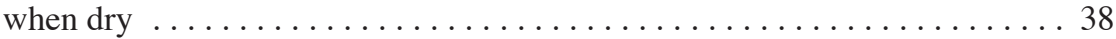

38a. Margin of the lamina coarsely crenate-dentate to subentire; ostiole c. $1 \mathrm{~mm}$ diam., surrounded by a sublobate rim; fruit (or endocarp body) distinctly tuberculate. - Sumatra, Malay Peninsula, Java, Borneo ........... 22. F. montana

b. Margin of the lamina closely denticulate; ostiole c. 2-3 mm diam., surrounded by a distinctly lobate rim; fruit (or endocarp body) smooth. $-\mathrm{N}$ Borneo . . . . .

36. F. subsidens

39a. Indumentum of leafy twig, petiole, and lamina beneath brownish; figs (sub) sessile, the receptacle $0.8-1.2 \mathrm{~cm}$ diam. when dry. $-\mathrm{N}$ Borneo . . 32. F. sandanakana

b. Indumentum of leafy twig, petiole, and lamina beneath whitish (and sparse); figs with a distinct peduncle, $(0.1-) 0.2-0.8 \mathrm{~cm}$ long, the receptacle $0.5-0.8 \mathrm{~cm}$ diam.

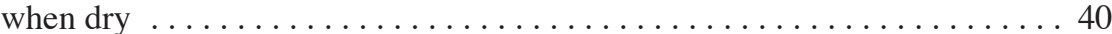

40a. Margin of the lamina coarsely crenate-dentate to subentire; ostiole c. $1 \mathrm{~mm}$ diam., surrounded by a sublobate rim; fruit (or endocarp body) distinctly tuberculate. - Sumatra, Malay Peninsula, Java, Borneo . . . . . . . . . 22. F. montana

b. Margin of the lamina closely denticulate; ostiole c. 2-3 mm diam., surrounded by a distinctly lobate rim; fruit (or endocarp body) smooth. $-\mathrm{N}$ Borneo . . . . . .

36. F. subsidens

41a. Stipules almost subulate and finely striate, often subpersistent (at least at the apices of leafy twigs); figs mostly ramiflorous to cauliflorous, in clusters. - Lesser Sunda Islands, Moluccas, New Guinea . . . . . . . . . . . . 41. F. wassa

b. Stipules subovate to lanceolate and chartaceous, not striate, caducous; figs axillary

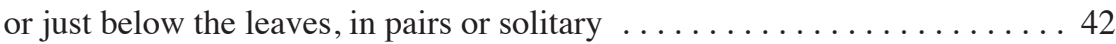

42a. Apex of lamina shortly acuminate to rounded; peduncle $0.2-1 \mathrm{~cm}$ long. - Java,

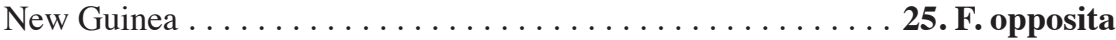

b. Apex of lamina acuminate to subcaudate or to subacute; figs sessile or with a peduncle up to $0.3 \mathrm{~cm}$ long. - N Borneo, Philippines, Sulawesi 8. F. cumingii

43a. Stipules fully amplexicaul, leaving annular scars (or only some of them semi-

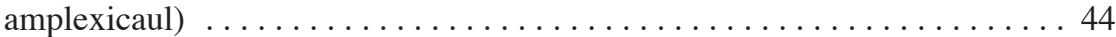

b. Stipules semi-amplexicaul to lateral, the scars not meeting opposite the base of

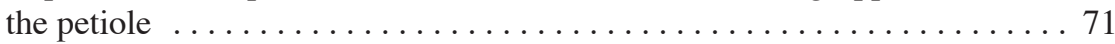

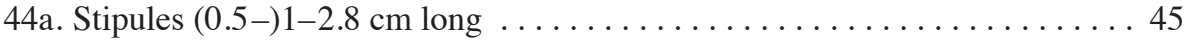

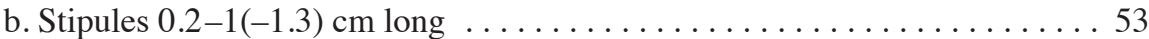

45a. Stipules subpersistent, striate and aristate. - Borneo . . . 64. F. rubromidotis

b. Stipules caducous, or if subpersistent, then not striate or aristate . . . . . . 46

46a. Stipules finely striate; midrib of the lamina clearly prominent; figs cauliflorous on clusters of leafless branchlets with short internodes. - Borneo . . . . . . . .

19. F. leptogramma

b. Stipules not finely striate; midrib of the lamina slightly prominent to flat; figs axillary, just below the leaves, or sometimes ramiflorous . . . . . . . . 47

47a. Leafy twigs, petioles, and/or stipules hairy, often sparsely and/or minutely so 48

b. Leafy twigs, petioles, and stipules entirely glabrous . . . . . . . . . . . . . 49

48a. Stipules dark brown when dry; base of the lamina \pm distinctly inequilateral and one side \pm clearly decurrent and often slightly to clearly (minutely) auricled; often 
additional waxy glands in the axils of the 2nd to 4th pairs of lateral veins or the single waxy gland in such positions and not in the axils of the basal lateral veins. - Widespread .....................67.F. subulata

b. Stipules greenish to pale brown when dry; base of the lamina hardly unilaterally decurrent and the waxy glands, 1 or 2 , in the axils of the basal lateral veins.

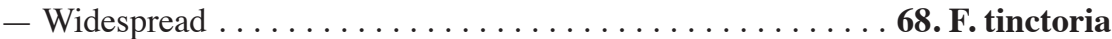

49a. Basal lateral veins up to $1 / 3-1 / 2$ the length of the lamina. - Sulawesi . . . . .

45. F. cauta

b. Basal lateral veins up to $1 / 20-1 / 3$ the length of the lamina . . . . . . . 50

50a. Stipules dark brown when dry, base of the lamina \pm distinctly inequilateral and one side \pm clearly decurrent and often slightly to clearly (minutely) auricled; often additional waxy glands in the axils of the 2nd to 4th pairs of lateral veins or the single waxy gland in such positions and not in the axils of the basal lateral veins. - Widespread .....................67.F. subulata

b. Stipules greenish to pale brown when dry; base of the lamina hardly unilaterally decurrent and the waxy glands, 1 or 2 , in the axils of the basal lateral veins . 51

51a. Lamina lanceolate-linear. - Sulawesi . . . . . . . . . 46. F. celebensis

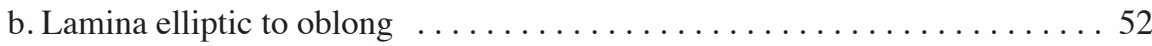

52a. Tertiary venation scalariform; apex of the lamina abruptly acuminate. - Philippines

53. F. inaequifolia

b. Tertiary venation reticulate to subscalariform, apex of the lamina \pm gradually acuminate. - Borneo, Philippines, Sulawesi, Lesser Sunda Islands, Moluccas, New Guinea . . . . . . . . . . . . . . . . . . . . . . . . . . . .

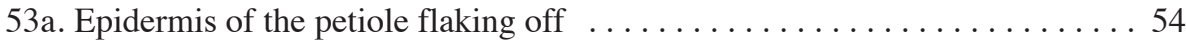

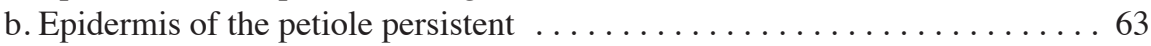

54a. Apex of the lamina acuminate to subacute (to acute) or rounded . . . . . . 55

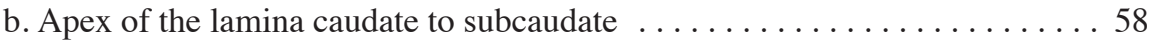

55a. Lamina chartaceous to subcoriaceous, margin bilaterally crenate-dentate to sublobate. - Sulawesi

42. F. anastomosans

b. Lamina coriaceous, margin entire or unilaterally sublobate . . . . . . 56

56a. Lamina with cystoliths (visible as minute pustules) only beneath; basal lateral veins mostly up to $1 / 3-1 / 2$ the length of the lamina; lamina drying (dark) brown.

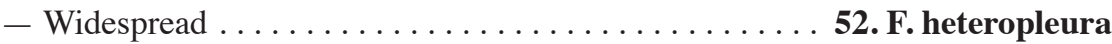

b. Lamina with cystoliths (visible as minute pustules) on both sides; basal lateral veins up to $1 / 8-1 / 3$ the length of the lamina; lamina drying greenish . . . . 57

57a. Leafy twigs and petioles entirely glabrous; epidermis of the petioles of the youngest leaves usually not yet flaking off. - Borneo, Philippines, Sulawesi, Lesser Sunda Islands, Moluccas, New Guinea . . . . . . . . . . 70. F. virgata

b. Leafy twigs and petioles minutely and sparsely hairy; epidermis of the petioles of the youngest leaves already flaking off. - Widespread ... 68. F. tinctoria

58a. Basal lateral veins up to $1 / 8-1 / 2$; lateral veins long, (most of them) curved; lamina often longer than $10 \mathrm{~cm}$; fig receptacle $(0.3-) 0.5-1 \mathrm{~cm}$ diam. when dry, the peduncle $(0.1-) 0.5-1.5 \mathrm{~cm}$ long. - Widespread ... 52. F. heteropleura

b. Basal lateral veins mostly up to $1 / 10-1 / 8$ the length of the lamina, or if up to $1 / 4$ the length, then the lateral veins short, running (almost) straight towards the 
margin, lamina shorter than $10 \mathrm{~cm}$, fig receptacle $0.2-0.5 \mathrm{~cm}$ diam. when dry,

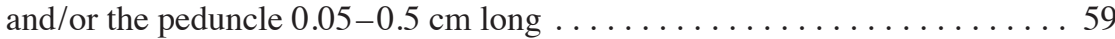

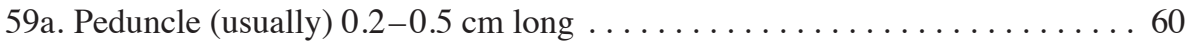

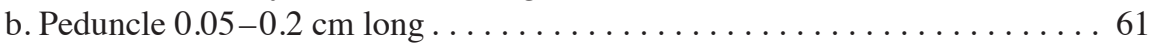

60a. Lamina with cystoliths (visible as minute pustules) only beneath; figs axillary or just below the leaves. - New Guinea . . . . . . . . . 49. F. gracillima

b. Lamina with cystoliths (visible as minute pustules) on both sides; figs flagelli-

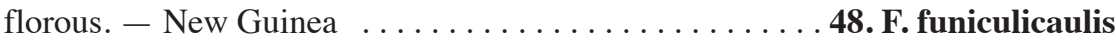

61a. Lower surface of the lamina hairy, although very sparsely. - Sumatra, Malay

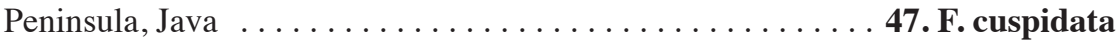

b. Lower surface of the lamina entirely glabrous . . . . . . . . . . 62

62a. Basal lateral veins weakly developed, up to $1 / 10$ the length of the lamina; base of

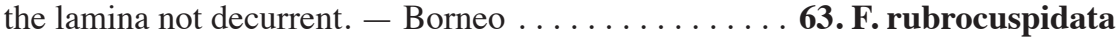

b. Basal lateral veins well-developed, up to $1 / 8-1 / 6$ the length of the lamina; base of the lamina decurrent at one side. - Borneo . . . . . . 57. F. leptocalama

63a. Lamina strongly asymmetric and the lobe of the broad side of the lamina base often covering the petiole; 2 waxy glands in the axils of the basal lateral veins at the broad side of the lamina and only 1 in the axil of the main basal lateral veins

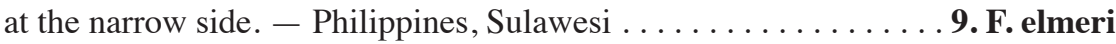

b. Lamina symmetric or \pm strongly asymmetric, but then not a lobe of the lamina base covering the petiole, with 2 glands (one in each of the axils of the (major) basal lateral veins), 1 gland in the axil of one of the (major) basal lateral veins, or also additional glands in the axils of other lateral veins . . . . . . . . . 64

64a. Basal lateral veins up to $1 / 2-2 / 3$ the length of the lamina; tertiary venation largely perpendicular to the midrib. - Sumatra, Malay Peninsula, Java, Borneo, Philip-

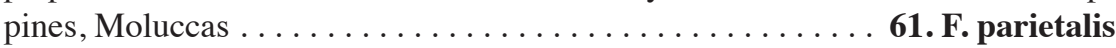

b. Basal lateral veins up to $1 / 10-1 / 2$ the length of the lamina; not largely perpen-

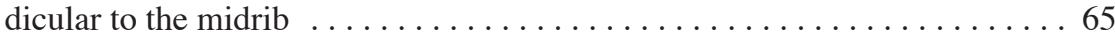

65 a. Basal lateral veins up to $1 / 4-1 / 2$ the length of the lamina . . . . . . . 66

b. Basal lateral veins up to $1 / 4$ the length of the lamina . . . . . . . . 68

66a. Basal lateral veins running \pm remotely from the margin of the lamina, branched; apex of the lamina shortly acuminate to rounded. - Widespread ..........

21. F. melinocarpa

b. Basal lateral veins running close to the margin of the lamina, unbranched; apex of the lamina acuminate to caudate . . . . . . . . . . . . . 67

67a. Waxy glands 2 , in the axils of both basal lateral veins; petiole $0.2-1 \mathrm{~cm}$ long; leafy twigs and petioles hairy, although minutely and/or sparsely. - Widespread ....

1. F. ampelas

b. Waxy gland 1, in the axil of one of the basal lateral veins; petiole $(0.5-) 1-2 \mathrm{~cm}$ long; leafy twigs and petiole entirely glabrous. - Sulawesi . . . 45. F. cauta

68a. Lamina scabrous above. - New Guinea . . . . . . . . . . . 43. F. armitii

b. Lamina smooth above . . . . . . . . . . . . . . . . . . . 69

69a. Petiole sparsely and minutely hispidulous; figs also ramiflorous and commonly clustered. - Sumatra, Malay Peninsula, Java, Borneo . . . . . . 65. F. sinuata

b. Petiole glabrous; figs axillary or just below the leaves and solitary or paired. 70 
70a. Waxy glands 2 (in the axils of both basal lateral veins); fig receptacle $0.8-1.2 \mathrm{~cm}$

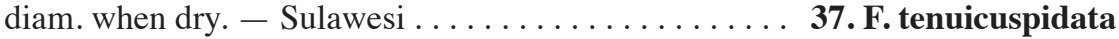

b. Waxy gland 1 (in the axil of one of the basal lateral veins); fig receptacle $0.3-0.8$ cm diam. when dry. - Borneo, Philippines, Sulawesi, Lesser Sunda Islands, Moluccas, New Guinea . . . . . . . . . . . . . . . 70. F. virgata

71a. Hairs (partly) uncinate. - Sumatra, Java . . . . . . . . 2. F. asperiuscula

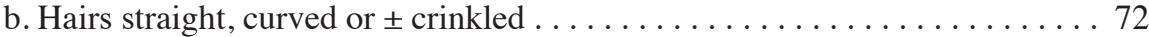

72a. Lamina strongly asymmetric and the lobe of the broad side of the lamina base often covering the petiole; 2 waxy glands in the axils of the basal lateral veins at the broad side of the lamina (or these glands extended to the midrib and then often fused) and only 1 in the axil of the main basal lateral veins at the narrow side; additional smaller waxy glands in the axils of other lateral veins present or

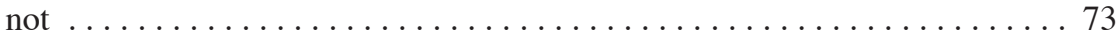

b. Lamina symmetric or \pm strongly asymmetric, but then not a lobe of the lamina base covering the petiole, with 2 glands (one in each of the axils of the (major) basal lateral veins), 1 gland in the axil of one of the (major) basal lateral veins, or also additional glands in the axils of other lateral veins . . . . . . . 75

73a. Leafy twigs and petioles coarsely hispidulous, scabrous, the hairs with strongly

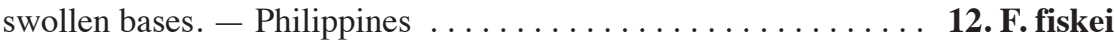

b. Leafy twigs and petioles puberulous to hirtellous or to subhispidulous, smooth (or scabridulous), the hairs without (strongly) swollen bases . . . . . . . . 74

74a. Additional waxy glands in the axils of other lateral veins than the basal ones present; fig receptacle 1-1.8 $\mathrm{cm}$ diam. when dry. - Philippines 24. F. odorata

b. Additional waxy glands in the axils of other lateral veins than the basal ones absent; fig receptacle $0.7-1 \mathrm{~cm}$ diam. when dry. - New Guinea . . 10. F. erinobotrya

75a. Lamina 8-17 $\mathrm{cm}$ broad, the midrib prominent above, the basal lateral veins 1/5-1/4 the length of the lamina, the tertiary venation subscalariform to reticulate, the base not prominently inequilateral. - Borneo . . . . . 54. F. jaheriana

b. Lamina (usually) less than $8 \mathrm{~cm}$ broad, if broader, then the midrib impressed above, the basal lateral veins $1 / 4-1 / 2$ the length of the lamina, the tertiary venation distinctly scalariform and/or the base prominently inequilateral . . . . 76

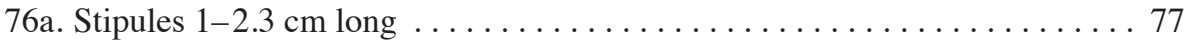

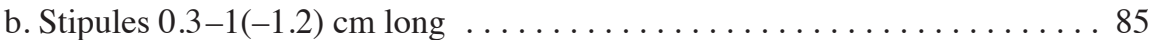

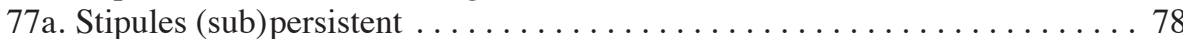

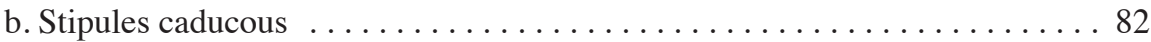

78a. Stipules not striate, with dense brown indumentum; base of the lamina at the broad side weakly auriculate or not . . . . . . . . . . . . 79

b. Stipules striate, with rather sparse and whitish or brownish indumentum or glabrous; base of the lamina at the broad side conspicuously auriculate, extended by an elliptic lobe with a midrib, or with a strip of mesophyll along the petiole .80

79a. Lamina slightly asymmetric to almost symmetric; basal lateral veins up to $1 / 4-1 / 3$ $(-1 / 2)$ the length of the lamina; waxy gland only 1 , in the axil of one of the basal lateral veins. - Sumatra . . . . . . . . . . . . 56. F. lasiocarpa

b. Lamina distinctly asymmetric; basal lateral veins up to $1 / 8-1 / 4$ the length of the lamina; waxy glands in addition to the one in the axil of one of the basal lateral veins mostly present in axils of other lateral veins. - Sumatra, Java, Borneo,

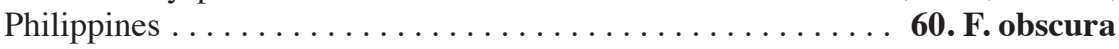


80a. Epidermis of the petiole not flaking off. - Sumatra . . . . . 66. F. stipata

b. Epidermis of the petiole $( \pm)$ flaking off $\ldots \ldots \ldots \ldots \ldots \ldots \ldots \ldots \ldots$

81a. Base of the lamina at the broad side extended by an auricle; additional small waxy glands usually present in the axils of other lateral veins than the basal ones. - Borneo ...................... 51.F. hemsleyana

b. Base of the lamina at the broad side extended by an elliptic lobe, or in smaller leaves just with a strip of mesophyll along the petiole; additional glands absent. - Moluccas, New Guinea ... . . . . . . . . . . . . . . 44. F. aurita

82a. Base of the lamina at one side decurrent, with a distinct auricle, an elliptic lobe with a midrib, or a strip of mesophyll along the petiole and/or an auricle or lobe

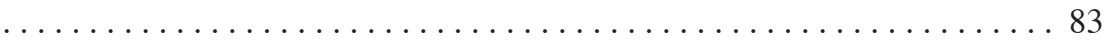

b. Base of the lamina at one side not decurrent with a strip of mesophyll along the

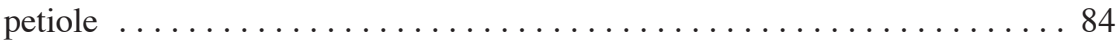

83a. Base of the lamina at the broad side auriculate; stipules not striate; small additional waxy glands in other than the basal lateral veins often present. - Borneo . . . . .

b. Base of the lamina at the broad side extended by an elliptic lobe with a midrib or in smaller leaves with a strip of mesophyll along the petiole; stipules not striate; additional waxy glands absent. - Borneo, Philippines, Sulawesi, Moluccas, New

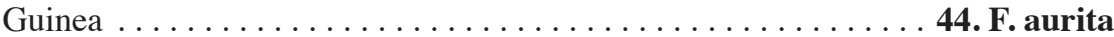

84a. Waxy glands 2, in the axils of both basal lateral veins; ostiole with a rosette of

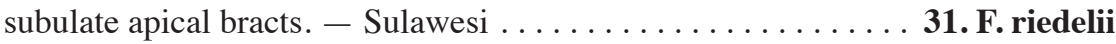

b. Waxy gland 1, in the axil of one of the basal lateral veins; ostiole with a rosette

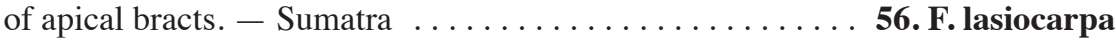

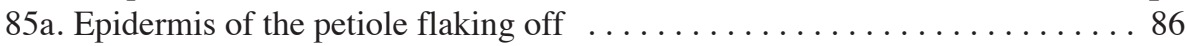

b. Epidermis of the petiole persistent $\ldots \ldots \ldots \ldots \ldots \ldots \ldots \ldots \ldots \ldots \ldots$

86a. Waxy glands 2, in the axils of both basal lateral veins; tertiary and smaller veins of the lamina \pm prominent beneath $\ldots \ldots \ldots \ldots \ldots \ldots \ldots \ldots \ldots$

b. Waxy gland 1 , in the axil of one of the basal lateral veins (or also smaller additional glands in the axils of other lateral veins than the basal ones); tertiary and smaller veins of the lamina flat or slightly prominent $\ldots \ldots \ldots \ldots 8$

$87 \mathrm{a}$. Indumentum of leafy twig and petiole yellowish or whitish; peduncle $0.1-0.3 \mathrm{~cm}$

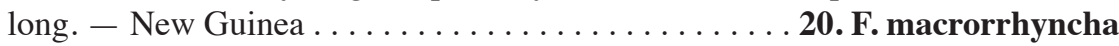

b. Indumentum of leafy twig and petiole brown; peduncle $0.5-1.2 \mathrm{~cm}$ long. - Phil-

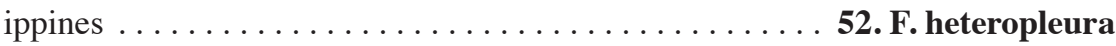

88a. Base of the lamina equilateral, not decurrent; additional waxy glands in the axils of other lateral veins than the basal ones absent. - Widespread

52. F. heteropleura

b. Base of the lamina inequilateral, at one side the base decurrent, or if slightly so, then additional waxy glands in the axils of other lateral veins than the basal ones usually present . . . . . . . . . . . . . . . . . . 89

89a. Petiole and lamina beneath entirely glabrous. - Sumatra, Malay Peninsula, Borneo, Philippines, Moluccas ............. 69. F. uniglandulosa

b. Petiole and lamina beneath hairy, at least sparsely and minutely hispidulous (and

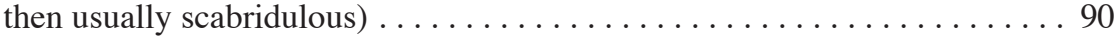


90a. Peduncle $0.3-1(-2.5) \mathrm{cm}$ long; additional waxy glands in other lateral veins than the basal ones usually present $\ldots \ldots \ldots \ldots \ldots \ldots \ldots \ldots \ldots . \ldots \ldots$ 59. midotis

b. Peduncle $0.1-0.3 \mathrm{~cm}$ long; additional waxy glands absent . . . . . . . . 91

91a. Indumentum brown(ish). - Borneo, Philippines, Sulawesi . . . 44. F. aurita

b. Indumentum whitish (often sparse and minute) . . . . . . . . . 92

92a. Additional waxy glands (in the axils of other lateral veins than the basal ones) absent; ostiole sunken; dried twigs changing in colour from dark red-brown to yellowish due to exfoliation of the periderm. - Sumatra, Malay Peninsula, Borneo, Philippines, Moluccas . . . . . . . . . 69. F. uniglandulosa

b. Additional waxy glands (in the axils of other lateral veins than the basal ones) usually present; ostiole not sunken, surrounded by a low rim; younger and older parts of the twigs not or hardly different in colour. - Borneo . 59. F. midotis

93a. Lamina glabrous and/or (almost) smooth above . . . . . . . . . . . . 94

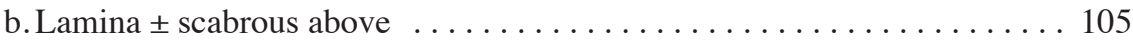

94a. Leafy twigs, petiole and midrib of the lamina beneath densely yellowish hairy; waxy glands 2 (in the axils of both basal lateral veins); petiole $0.5-1.5 \mathrm{~cm}$ long; fig receptacle $0.5-0.7 \mathrm{~cm}$ diam. when dry. - New Guinea .

20. F. macrorrhyncha

b. Leafy twigs sparsely hairy or glabrous, or if densely hairy, then the indumentum brown, the waxy gland 1 (in the axil of one of the basal lateral veins), the petiole $0.3-0.6 \mathrm{~cm}$ long, and the fig receptacle $0.3-0.5 \mathrm{~cm}$ diam. when dry . . . . 95

95a. Lamina lanceolate; lateral veins 11-16 pairs, departing at wide angles, up to $90^{\circ}$; basal lateral veins up to $1 / 20-1 / 10$ the length of the lamina. - N Borneo,

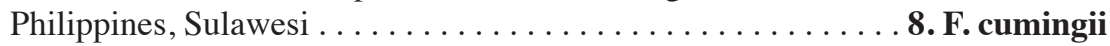

b. Lamina elliptic to oblong to subobovate, or if lanceolate, then the lateral veins (3-)4-11 pairs and/or the basal lateral veins up to $1 / 6$ the length of the lamina 96

96a. Stipules subpersistent, striate; basal lateral veins up to $1 / 3-1 / 2$ the length of the lamina; waxy gland 1 (in the axil of one of the basal lateral veins). - Borneo .

55. F. kuchinensis

b. Stipules caducous; basal lateral veins up to $1 / 8-1 / 4$ the length of the lamina, or if up to $1 / 3-1 / 2$ the length of the lamina, then waxy glands 2 (in the axils of

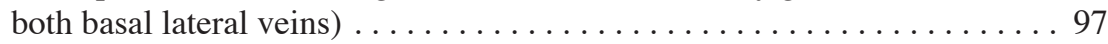

97a. Leafy twig and petiole entirely glabrous or the petiole hairy only at the margins

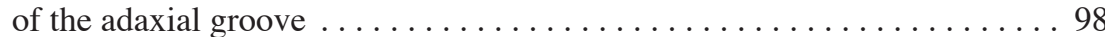

b. Leafy twig and petiole hairy, often minutely and inconspicuously . . . . . 103

98a. Basal lateral veins up to $1 / 3-1 / 2$ the length of the lamina . . . . . . . . . . 99

b. Basal lateral veins up to $1 / 6-1 / 3$ the length of the lamina . . . . . . . 101

99a. Basal lateral veins branched at least at the broad side of the lamina. - New Guinea ....................... 29.F.pseudowassa

b. Basal lateral veins unbranched ...................... 100

100a. Tertiary venation regularly scalariform; apex of the lamina (sub)acuminate to subacute; margin of the lamina flat. - New Guinea ... . . 18. F. leptodictya

b. Tertiary venation loosely scalariform; apex of the lamina shortly and \pm abruptly acuminate to rounded; margin of the lamina usually \pm revolute. - Sulawesi . . 
101a. Peduncle $0.4-0.5 \mathrm{~cm}$ long; petiole hairy only at the margins of the adaxial groove

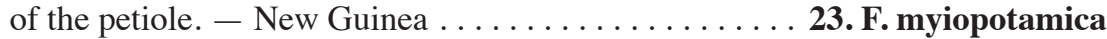

b. Peduncle $0.5-1.2 \mathrm{~cm}$ long; petiole entirely glabrous . . . . . . . . . 102

102a. Tertiary venation regularly scalariform; apex of the lamina (sub)acuminate to subacute; margin of the lamina flat. - New Guinea ... . . 18. F. leptodictya

b. Tertiary venation loosely scalariform; apex of the lamina shortly and \pm abruptly acuminate to rounded; margin of the lamina usually \pm revolute. - Sulawesi . .

38. F. tonsa

103a. Basal lateral veins branched at least at the broad side. - E New Guinea . . . . .

29. F. pseudowassa

b. Basal lateral veins unbranched . . . . . . . . . . . . . . . . . . . 104

104a. Lamina with cystoliths (visible as minute pustules) only beneath; fig receptacle $0.2-0.4 \mathrm{~cm}$ diam. when dry, sessile or with a peduncle up to $0.2 \mathrm{~cm}$ long. - Phil-

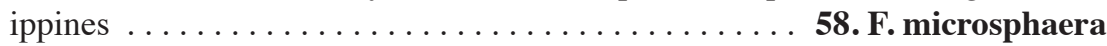

b. Lamina with cystoliths (visible as minute pustules) on both sides; fig receptacle $0.3-1(-1.5) \mathrm{cm}$ diam. when dry; peduncle $0.2-1.2(-2.5) \mathrm{cm}$ long. - Wide-

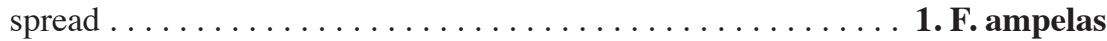

105a. Waxy gland at the base of the midrib . . . . . . . . . . . 106

b. Waxy glands in the axils of lateral veins, only the basal ones or also others 107

106a. Basal lateral veins of the lamina unbranched or faintly branched; figs axillary. E New Guinea .................... 33. F. schumanniana

b. Basal lateral veins at the broad side of the lamina branched; figs often also (far) below the leaves. - E New Guinea ........... 29. F. pseudowassa

107a. Lamina obliquely rhombic; fig receptacle $1.5-2 \mathrm{~cm}$ diam. when dry. - Sulawesi $\ldots \ldots \ldots \ldots \ldots \ldots \ldots \ldots \ldots \ldots \ldots \ldots \ldots \ldots \ldots \ldots \ldots \ldots$ 14. F. goniophylla

b. Lamina not rhombic; fig receptacle $0.3-1.3(-1.5) \mathrm{cm}$ diam. when dry . . 108

108a. Waxy gland 1 , in the axil of one of the basal lateral veins, or also additional ones in the axils of other lateral veins . . . . . . . . . . . . . . . . . . . . 109

b. Waxy glands 2 , in the axils of both basal lateral veins . . . . . . . . 110

109a. Lamina smooth; waxy glands only in the axil of one of the basal lateral veins. - Sumatra, Java, Sulawesi, Moluccas . . . . . . . . 50. F. grewiifolia

b. Lamina scabrous, at least above; additional waxy glands mostly present in the axils of other lateral veins than the basal ones. - Sumatra, Malay Peninsula,

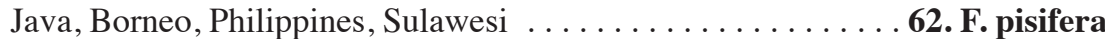

110a. Basal lateral veins up to $1 / 20-1 / 10$ the length of the lamina; lamina linearlanceolate. - N Borneo, Philippines, Sulawesi . . . . . . 8. F. cumingii

b. Basal lateral veins up to $1 / 6-1 / 2$ the length of the lamina; lamina oblong to subovate .............................. 111

111a. Shrubs usually up to c. $3 \mathrm{~m}$ tall, prostrate and rooting on the stems, sometimes \pm climbing (straggling); base of the lamina not decurrent at one side. - Malay

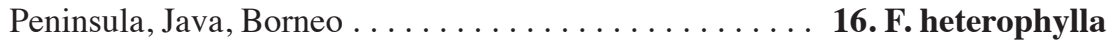

b. Trees, or if shrubs, then not prostrate with rooting stems, or if climbing, then with the base of the lamina decurrent at one side $\ldots \ldots \ldots \ldots \ldots 112$

112a. Basal lateral veins up to $1 / 6-1 / 4$ the length of the lamina . . . . . . . 113

b. Basal lateral veins up to $1 / 4-1 / 2$ the length of the lamina $\ldots \ldots \ldots \ldots 115$ 
113a. Lamina with cystoliths (visible as minute pustules) only beneath; base of the lamina at one side decurrent and auricled; petiole $0.2-0.6(-0.8) \mathrm{cm}$ long; often lianescent and/or epiphytic. - New Guinea . . . . . . . . . 43. F. armitii

b. Lamina with cystoliths (visible as minute pustules) on both sides; base of the lamina not decurrent or auricled; petiole $0.5-1.5(-2) \mathrm{cm}$ long; always terrestrial

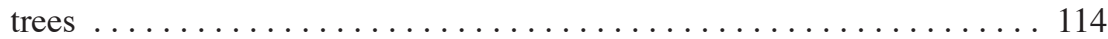

114a. Lamina with the smaller veins prominent beneath, the upper surface often \pm bullate; fig receptacle $0.5-0.8 \mathrm{~cm}$ diam. when dry, scabrous. - Sulawesi, Moluccas, New Guinea ...................... 39. F. trachypison

b. Lamina with the smaller veins almost flat beneath, the upper surface not bullate; fig receptacle $0.9-1.2 \mathrm{~cm}$ diam. when dry, smooth. - E New Guinea ......

29. F. pseudowassa

115a. Tertiary and smaller veins prominent beneath; indumentum on the leafy twigs and lamina beneath usually dense and conspicuous $\ldots \ldots \ldots \ldots \ldots$

b. Tertiary and smaller veins flat or only slightly prominent beneath; indumentum of the leafy twigs and lamina beneath sparse and/or inconspicuous . . . . 118

116a. Waxy glands also in the axils of other lateral veins than the basal ones. - Sulawesi, Moluccas, New Guinea .............. 39. F. trachypison

b. Waxy glands only in the axils of the basal lateral veins . . . . . . . . 117

117a. Basal lateral veins up to $1 / 3-1 / 2$ the length of the lamina; lamina not bullate above; ostiole receptacle surrounded by a rosette of apical bracts pointing up-

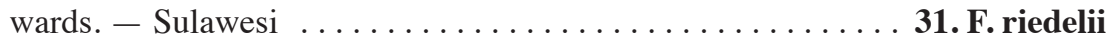

b. Basal lateral veins up to $1 / 4-1 / 3(-1 / 2)$ the length of the lamina; lamina \pm bullate

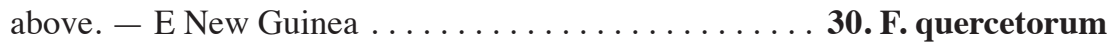

118a. Petiole 0.2-1 cm long; base of the lamina slightly inequilateral and the lateral veins unbranched or faintly branched. - Widespread ...... 1.F. ampelas

b.Petiole (0.5-)1-3 cm long and/or the base of the lamina usually distinctly inequilateral and the basal lateral veins at least at the broad side of the lamina

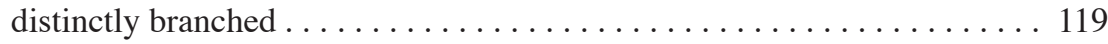

119a. Upper surface of the lamina glabrous; figs also ramiflorous and cauliflorous.

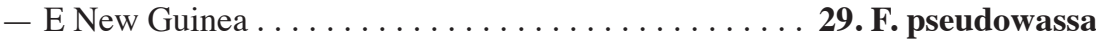

b. Upper surface of the lamina (sparsely) hispidulous; figs usually only axillary .

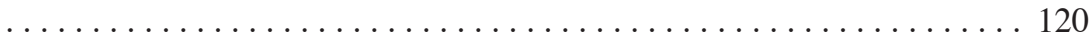

120a. Peduncular bracts $0.5-1 \mathrm{~mm}$ long; ostiole surrounded by apical bracts, these and the narrow outer ostiolar bracts pointing upwards. - Philippines . . . . . . . .

40. F. ulmifolia

b. Peduncular bracts 1-2 mm long; ostiole surrounded by a low rim and the broad upper ostiolar bracts not pointing upwards. - E New Guinea . 35. F. stellaris

\section{ACKNOWLEDGEMENTS}

The Flora Malesiana Foundation supports the preparation of the treatment of Moraceae for Flora Malesiana. Dr. J.F. Veldkamp (Leiden) translated the diagnoses into Latin. Hendrieke Berg (Voss, Norway) prepared the drawings. 


\section{REFERENCES}

Berg, C.C. 2000. Ficus corneriana, a new species of Ficus subg. Sycidium sect. Palaeomorphe (Moraceae) from the Solomon Islands. Blumea 45: 397-398.

Berg, C.C. 2003. Flora Malesiana precursor for the treatment of Moraceae 1: The main subdivision of Ficus: the subgenera. Blumea 48: 167-178.

Corner, E.J.H. 1960a. Taxonomic notes on Ficus Linn., Asia and Australasia. III. Subgen. Ficus and sect. Ficus. Gard. Bull. Singapore 17: 416-441.

Corner, E.J.H. 1960b. Taxonomic notes on Ficus Linn., Asia and Australasia. IV. Subgen. Ficus sect. Sycidium Miq.. Gard. Bull. Singapore 17: 442-485.

Corner, E.J.H. 1960c. Taxonomic notes on Ficus Linn., Asia and Australasia. V. Subgen. Ficus sect. Rhizocladus, Kalosyce, Sinosycidium, Adenosperma, and Neomorphe. Gard. Bull. Singapore 18: $1-35$.

Corner, E.J.H. 1965. Check-list of Ficus in Asia and Australasia with a key to identification. Gard. Bull. Singapore 21: 1-186.

Corner, E.J.H. 1970. Ficus subg. Ficus. Two rare primitive pachycaul species. Philos. Trans., Ser B, 259: 353-381.

King, G. 1887. The species of Ficus of the Indo-Malayan and Chinese countries. Ann. Roy. Bot. Gard. (Calcutta) 1, 1: 1-66, t. 1-87.

Kochummen, K.M. 1998. New species of Moraceae from Malaysia. Gard. Bull. Singapore 50: 197-219.

Mildbraed, J. \& M. Burret. 1912. Die afrikanischen Arten der Gattung Ficus Linn. Bot. Jahrb. Syst. 46: $175-269$.

Miquel, F.A.W. 1848. Prodromus Monographiae Ficuum. London J. Bot. 7: 221-236. 